2. To: (Receiving Organization)

FDH Facility Stabilization

5. Proj/Prog//Dept/Div::

300 Area Stabilization Project

8. Originator Remarks:

This document is for public release.

11. Receiver Remarks: 11A. Design Baseline Document? [] Yes [X] No
6. Design Authority/ Design Agent/Cog. Engr.:

R. L. Hobart

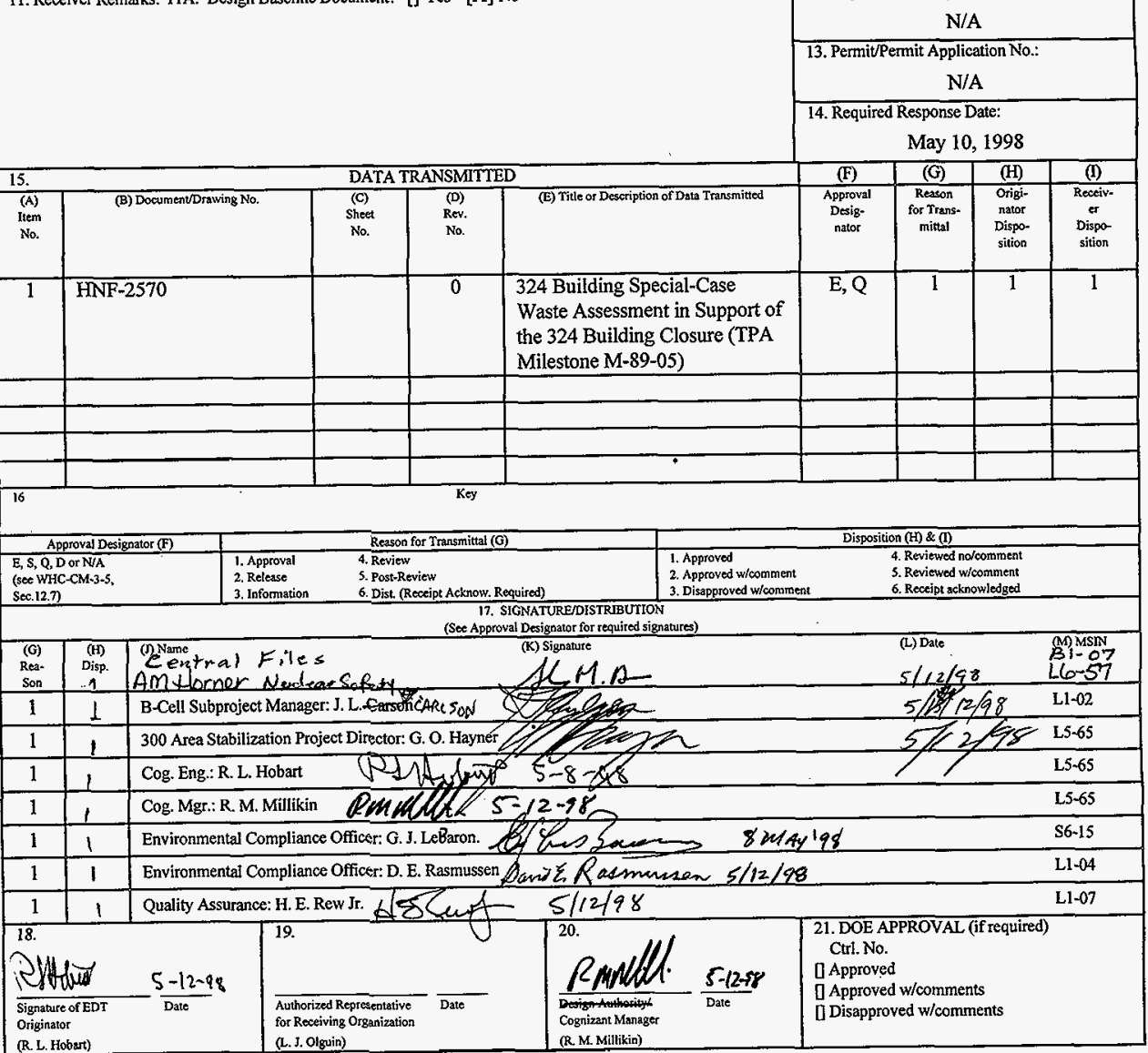




\section{RELEASE AUTHORIZATION}

Document Number: HNF-2570, Revision 0

324 Building Special-Case Waste Assessment

Document Title: - in Support of the 324 Building Closure

(TPA Milestone M-89-05)

This document, reviewed in accordance with DOE Order 1430.1D. "Scientific and Technical Information Management," and DOE G 1430.1D-1, "Guide to the Management of Scientific and Technical Information," does not contain classified or sensitive unclassified information and is:

\section{APPROVED FOR PUBLIC RELEASE}

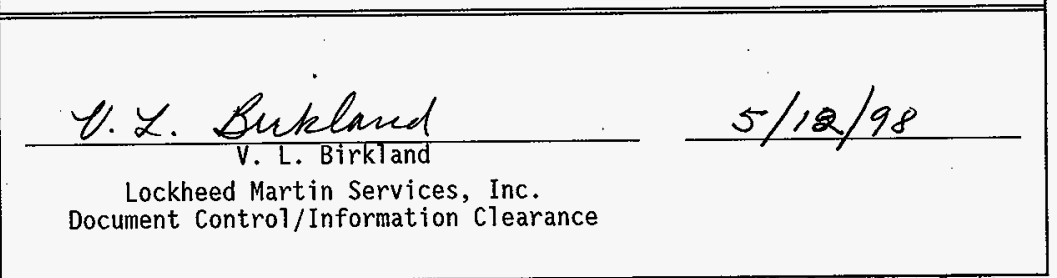

Reviewed for Applied lechnology, Business Sensitive, Classitied, Copyrighted, Export Controlled, Patent, Personal/Private, Proprietary, Protected CRADA, Trademark, Unclassified Controlled Nuclear Information.

Trademark Disclaimer. Reference herein to any specific commercial product, process, or service by trade name, trademark, manufacturer, or otherwise, does not necessarily constitute or imply its endorsement, recommendation, or favoring by the United States Government or any agency thereof or its contractors or subcontractors. The views and opinions of authors expressed herein do not necessarily state or reflect those of the United States Govemment or any agency thereof. This report has been reproduced from the best available copy.

Printed in the United States of America.

Available to the U.S. Department of Energy and its contractors from the U.S. Department of Energy Office of Scientific and Technical Information, P.O. Box 62, Oak Ridge, TN 37831; Telephone: 423/576-8401.

Available to the public from the U.S. Department of Commerce Nationat Technical Information Service, 5285 Port Royal Road, Springfield, VA 22161; Telephone: 703/487-4650. 
HNF-2570, Rev. 0

\title{
324 Building \\ Special-Case Waste Assessment in Support of the 324 Building Closure (TPA Milestone M-89-05)
}

\author{
R. L. Hobart \\ B\&W Hanford Company, Richland, WA 99352 \\ U.S. Department of Energy Contract DE-AC06-96RL13200
}

EDT/ECN: 616484

Org Code: 19400

B\&R Code: EW3130010
UC: 2000

Charge Code: K4BGA (HAN98300)

Total Pages: 74 , 86

Key Words: Tri-Party Agreement, special-case waste, decontamination and decommissioning, U.S.

Department of Energy, Plutonium Uranium Extraction Facility (PUREX), spent nuclear fuel, solid waste disposal box.

\section{Abstract:}

Hanford Federal Facility Agreement and Consent Order, also known as the Tri-Party Agreement Milestone M-89-05 requires U.S. Department of Energy, Richland Operations Office to complete a A324 Building Special Case Waste Assessment in Support of the 324 Building Closure, (This document, HNF-2570, has been prepared with the intent of meeting this regulatory commitment.

TRADEMARK DISCLAIMER. Reference herein to any specific commercial product, process, or service by trade name, trademark, manufacturer, or otherwise, does not necessarily constitute or imply its endorsement, recommendation, or favoring by the United States Government or any agency thereof or its contractors or subcontractors.

Printed in the United States of America. To obtain copies of this document, contact: Document Control Services, P.O. Box 950, Mailstop H6-08, Richland WA 99352, Phone (509) 372-2420; Fax (509) 376-4989
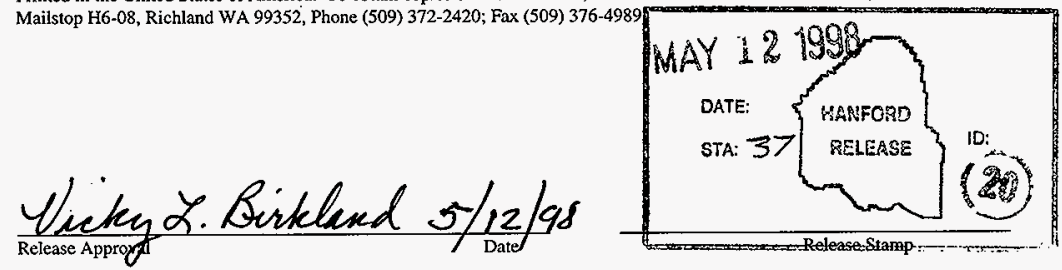

\section{Approved for Public Release}




\section{Building}

\section{Special-Case Waste Assessment}

in Support of the 324 Building Closure (TPA Milestone M-89-05)

HNF-2570, Rev. 0

May 1998

prepared for:

United States Department of Energy - Richland Operations Office Richland, Washingtor

prepared by:

B\&W Hanford Company 
HNF-2570, Rev. 0

Page left intentionally blank. 
HNF-2570, Rev. 0

\section{EXECUTIVE SUMMARY}

Hanford Federal Facility Agreement and Consent Order, also known as the Tri-Party Agreement, Milestone M-89-05 requires U.S. Department of Energy, Richland Operations Office to complete a "324 Building Special Case Waste Assessment in Support of the 324 Building Closure." This document, HNF-2570, has been prepared with the intent of meeting this regulatory commitment.

Alternatives for the Special Case Wastes located in the 324 Building were defined and analyzed. Based on the criteria of safety, environmental, complexity of interfaces, risk, cost, schedule, and long-term operability and maintainability, the best alternative was chosen. Waste packaging and transportation options are also included in the recommendations. The waste disposition recommendations for the B-Cell dispersibles/tank heels and High-Level Vault packaged residuals are to direct them to the Plutonium Uranium Extraction Facility (PUREX) Number 2 storage tunnel. 
HNF-2570, Rev. 0

Page left intentionally blank. 


\section{Building Special-Case Waste Assessment in Support of 324 Closure}

\section{TABLE OF CONTENTS}

1.0 BACKGROUND AND PURPOSE

1.1 Introduction

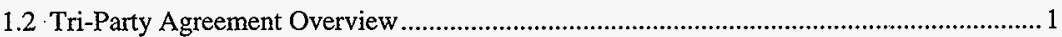

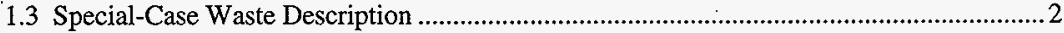

1.4 Purpose

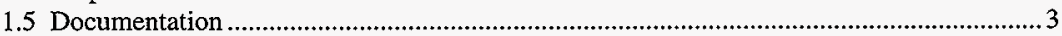

2.0324 SPECIAL-CASE WASTE IN SUPPORT OF CLOSURE ...........................................5

2.1 B-Cell Dispersible Debris, Tank Heels, and Pipe Trench Sludge ...........................................5

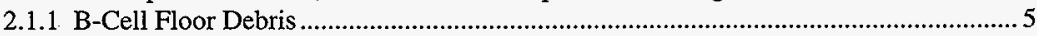

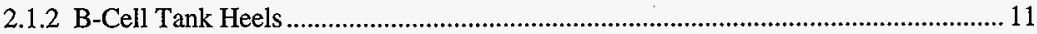

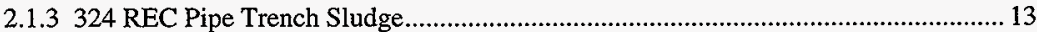

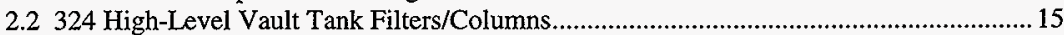

2.2.1 Detailed Description.............................................................................................. 15

2.2.2 Volume

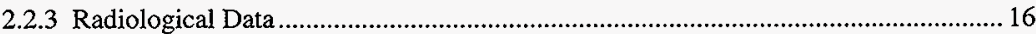

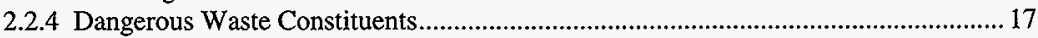

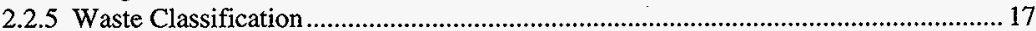

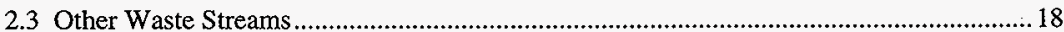

2.4 Previously Dispositioned 324 SCW In PUREX Tunnel ................................................. 19

3.0 REQUIREMENTS ANALYSIS......................................................................................... 21

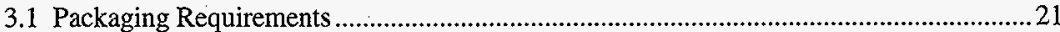

3.1.1 Central Waste Complex/Burial Grounds Packaging Requirements......................... 22

3.1.2 Canyon Facility Packaging Requirements................................................................... 23

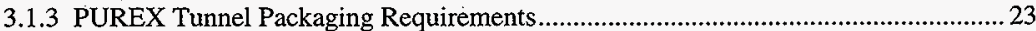

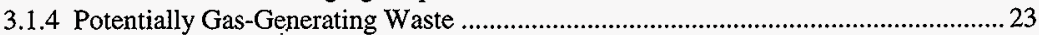

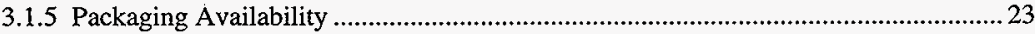

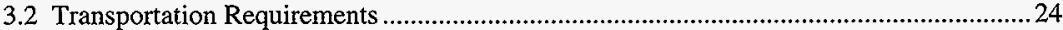

3.2.1 Shipment of Casks by Truck ........................................................................................... 24

3.2.2 Shipment of Boxes by Truck .................................................................................... 24

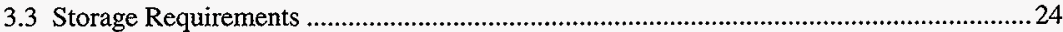

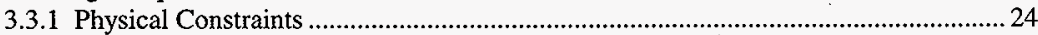

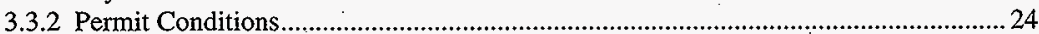

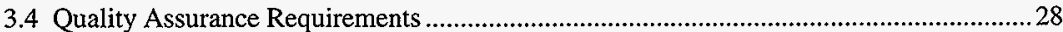

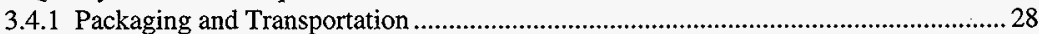

3.4.2 Storage and Physical Facility Upgrades ...................................................................2 29

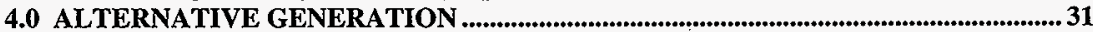

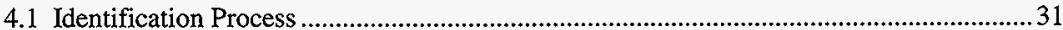

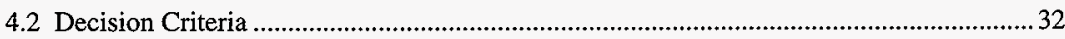

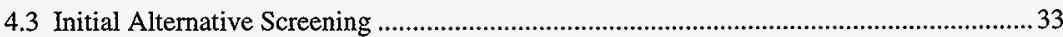

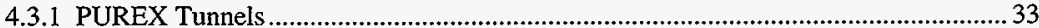

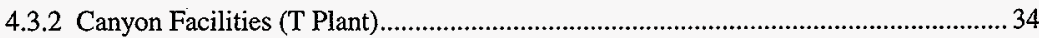


4.3.3 Central Waste Complex Building/Storage Pad/Burial Grounds ................................. 37

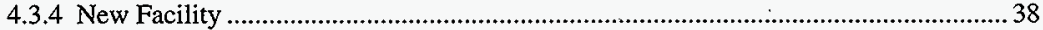

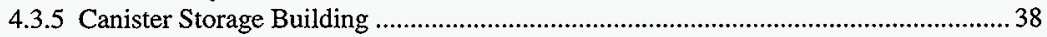

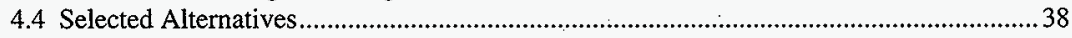

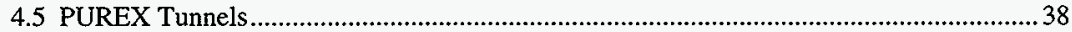

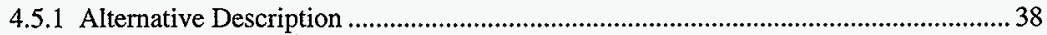

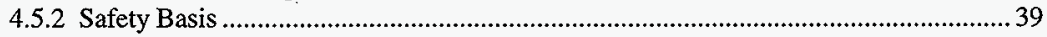

4.5.3 Permit Condition .................................................................................................... 40

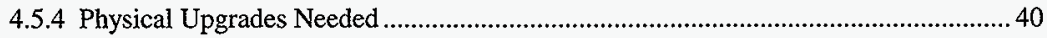

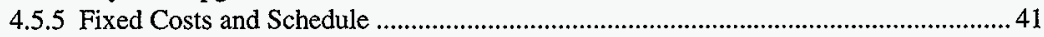

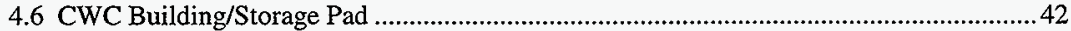

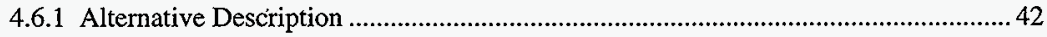

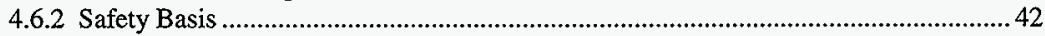

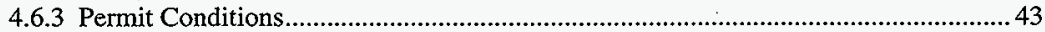

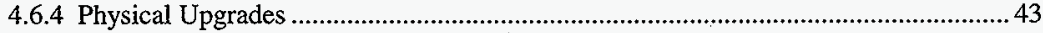

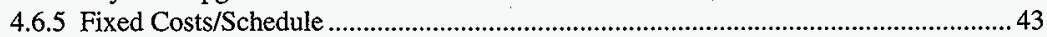

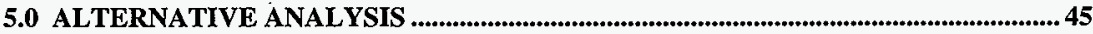

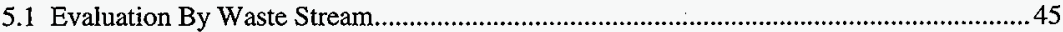

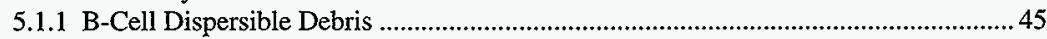

5.1.2 High Level Vault Tank Residuals .............................................................................50

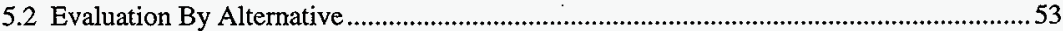

6.0 RECOMMENDED STORAGE SOLUTION .........................................................55

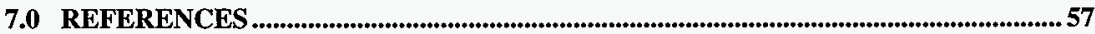

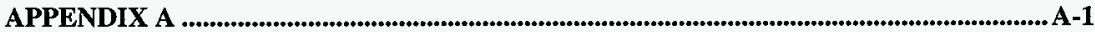

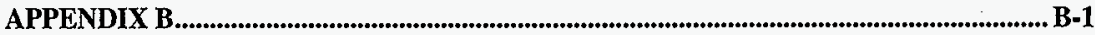

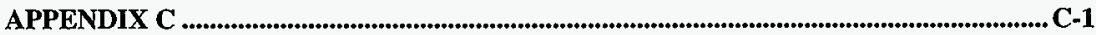


HNF-2570, Rev. 0

\section{FIGURE}

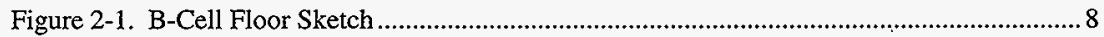

\section{TABLES}

Table 2-1. B-Cell Dispersibles Waste Quick Reference.

Table 2-2. B-Cell Debris Sample Results from PNL-10623 ........................................................9

Table 2-3. B-Cell Dispersible Debris Sample Results from Waste Manifests 96004 and 96006.10

Table 2-4. Reference Drawings for B-Cell Tanks. ........................................................................ 11

Table 2-5. B-Cell Tank Heel Waste Volume. ........................................................................ 12

Table 2-6. Tank Heel Estimated Curie Content*..................................................................... 13

Table 2-7. HLV Residual Waste Stream Quick Reference.............................................................. 16

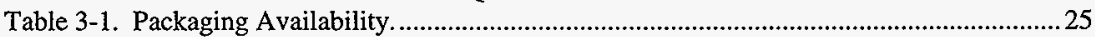

Table 4-1. Summary of Fixed Cost and Schedule for PUREX Tunnel Options............................41

Table 4-2. Summary of Fixed Costs and Schedule for CWC Alternative. ....................................4 44

Table 5-1. DE-Ci Calculations for 1996 Shipment of B-Cell Dispersible Debris and Feed Cans under Pin \# PNL-324-96-005, Manifest 96-004 ...............................................................4 47

Table 5-2. Packaging Approach for Storage of the B-Cell Dispersibles at CWC........................48

Table 5-3. Packaging Approach for Storage of HLV Residuals at CWC. ...................................51

Table 5-5. Shipping Approaches for Sending the HLV Residuals to the CWC..........................52

Table 5-6. Alternative Evaluation Summary.............................................................................53

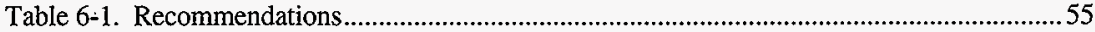

Table A-1. Metal Filters Dangerous Waste Concentration. .......................................................

Table A-2. Strontium Filter \#4...........................................................................................

Table A-3. Strontium Filter \#5 ...............................................................................

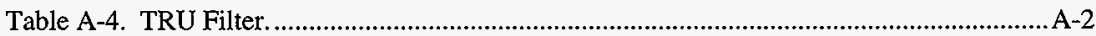

Table B-1. B-Cell Dispersible Prepackaging Costs. .................................................................... B-1

Table B-2. B-Cell Dispersible Packaging Costs. ………................................................... B-1

Table B-3. B-Cell Dispersible Transportation Costs........................................................... B-2

Table B-4. B-Cell Dispersible Placement Costs. ………................................................................ B-2

Table B-5. 324 HLV Filter and Ion Exchange Column Prepackaging Costs........................... B-3

Table B-6. 324 HLV Filter and Ion Exchange Column Packaging Costs................................... B-3

Table B-7. 324 HLV Filter and Ion Exchange Column Transportation Costs........................... B-4

Table B-8. 324 HLV Filter and Ion Exchange Column Placement Costs................................... B-4 
HNF-2570, Rev. 0

Page left intentionally blank.

viii 


\section{TERMS}

BIO Basis of Interim Operation

BWHC B\&W Hanford Company

CERCLA Comprehensive Environmental Response Compensation, Recovery and Liability Act of 1980

CFR Code of Federal Regulations

Cs cesium

CSB Canister Storage Building

CWC Central Waste Complex

D\&D decontamination and decommissioning

DOE U.S. Department of Energy

DW dangerous waste

EA environmental assessment

ECN Engineering Change Notice

Ecology Washington State Department of Ecology

EPA U.S. Environmental Protection Agency

FRG Federal Republic of Germany

GTC3 Greater-Than-Category-3

GTCC Greater-Than-Class-C

HEPA high-efficiency particulate air

HLV High-Level Vault

ISB Interim Safety Basis

IX ion exchange

LLW low-level waste

LLMW Iow-level mixed waste

MW mixed waste

NEPA National Environmental Policy Act of 1969

NOC Notice of Construction

NRC U.S. Nuclear Regulatory Commission

PNNL Pacific Northwest National Laboratory

PUREX Plutonium Uranium Extraction Facility 
HNF-2570, Rev. 0

RCRA Resource Conservation Recovery Act of 1976

REC Radiochemical Engineering Cells

RL U.S. Department of Energy, Richland Operations Office

SARP Safety Analysis Report for Packaging

SCW special-case waste

SEP Safety Evaluation for Packaging

S\&M surveillance and maintenance

SNF spent nuclear fuel

$\mathrm{Sr} \quad$ strontium

SWB standard waste box $(4 \times 4 \times 8 \mathrm{ft}$. box $)$

SWDB steel waste disposal box ( $22 \frac{1}{2}$-ton box)

SWBG solid waste burial grounds

TPA Hanford Federal Facility Agreement and Consent Order, also known as the Tri-Party Agreement

TRU transuranic

TSD treatment, storage, and disposal

USQ Unreviewed Safety Question

WDOH Washington State Department of Health

WMH Waste Management Federal Services of Hanford, Inc.

$\begin{array}{ll}\mathrm{Ci} & \text { Curies } \\ \mathrm{cm} & \text { centimeters } \\ \mathrm{KCi} & \text { Kilo Curies } \\ \mathrm{kg} & \text { kilogram } \\ \mathrm{MCi} & \text { Mega Curies } \\ \mathrm{mg} / \mathrm{mL} & \text { milligrams per milliliter } \\ \mathrm{mrem} & \text { millirem } \\ \mathrm{nCi} / \mathrm{g} & \text { nano Curies per gram } \\ \mathrm{ppm} & \text { parts per million }\end{array}$


HNF-2570, Rev. 0

\subsection{BACKGROUND AND PURPOSE}

\subsection{Introduction}

Alternatives for the special-case waste (SCW) for the Hanford 300 Area, 324 and 327 Buildings, were defined and analyzed in HNF-1730, 324/327 Facilities Special-Case Waste. Assessment and Disposition Alternatives Analysis. Based on the criteria of safety, environmental complexity, organization interfacing, risk, cost, schedule, and long-term operability, the best alternatives were proposed. Using the results of HNF-1730, this report has been prepared to specifically address the SCW disposition strategy related to the SCW managed by the 324 Building, which are affected by the 324 Building closure actions as required by Hanford Federal Facility Agreement and Consent Order, also known as the Tri-Party Agreement (TPA) Milestone M-89-05.

The 324 Building is operated for the U.S. Department of Energy, Richland Operations Office (RL), by B\&W Hanford Company (BWHC). The 324 Building contains significant quantities of high-dose-rate nuclear material and waste requiring storage or disposal outside the 300 Area. Because the high activity levels of the waste and associated difficulties in characterizing, classifying, and packaging it to meet the Hanford Site Solid Waste Acceptance Criteria (Willis 1993), they are listed as SCW. Special-case waste is defined in Section 1.3, SCW Description, and is managed under TPA (Ecology et al) major milestone M-33-00 and subsequently under major milestone M-92-00 (see Section 1.2, TPA Overview).

\subsection{Tri-Party Agreement Overview}

The TPA is an agreement between the U.S. Department of Energy (DOE), the U.S. Environmental Protection Agency (EPA), and the Washington State Department of Ecology (Ecology) to complete cleanup of the Hanford Site as required by the Resource Conservation and Recovery Act of 1976 (RCRA) and the Comprehensive Environmental Response, Compensation, and Liability Act of 1980 (CERCLA). The TPA terms and conditions provide the legal framework, required actions and schedules (milestones) for site cleanup. The purpose of the TPA is to require DOE compliance with RCRA requirements for treatment, storage, and disposal (TSD) units, and RCRA and CERCLA requirements for interim and final remedial actions.

The Fourth Amendment to the TPA (January 1994) added major Milestone M-33-00, which required that the DOE accomplish the following:

- Identify a path forward for disposition of Hanford Site solid waste and materials.

- Submit a TPA change package to add milestones for acquisition of the necessary TSD facilities to implement the path forward.

The waste streams that were considered in the scope of Milestone M-33-00 included the SCW in the 300 Area that did not have a clearly defined disposition pathway. 
In negotiations between RL, Ecology, and the EPA in 1995 and 1996, it was agreed that Major Milestone M-33-00 would be replaced by a series of decision point milestones for disposition of each major waste stream. The decisions ultimately would lead to specific interim milestones and target dates for acquiring the necessary TSD facilities.

Major Milestone M-92-00 and its associated interim milestones and target dates [refer to Change Number M-92-96-01 (Ecology 1996)] were established to govern the acquisition of new facilities, modification of existing facilities, and/or modification of planned facilities needed to store, treat, and dispose of Hanford Site cesium, strontium, unirradiated uranium, bulk sodium, and 300 Area SCW. Amendment 5 to the TPA also added major milestone M-89-00 and associated interim milestone and target dates for closure of the nonpermitted mixed waste (MW) units located in the 324 Building and for compliance actions required under RCRA for the same MW units. The specific areas of the 324 Building considered to be MW units are described in the 324 Building Radiochemical Engineering Cells, High-Level Vault, Low-Level Vault and Associated Areas Closure Plan (DOE/RL-96-73). Tri-Party Agreement Milestone M-89-05 requires RL to complete a "324 Building Special Case Waste Assessment in Support of the 324 Building Closure."

\subsection{Special-Case Waste Description}

The initial determination of what was considered to be SCW was not well documented. Tri-Party Agreement Change Package M-92-96-01 (Ecology 1996) listed all materials and waste initially identified as SCW by Pacific Northwest National Laboratory (PNNL). This change package also describes a process to use for revising the SCW list. In some cases, waste and material were previously listed as SCW without complete characterization or exact determination of curie content, volume, and classification of waste versus material. As the characterization data for the SCW waste streams have improved and waste classifications have been identified, the number of SCW streams without a clearly defined disposition strategy has been reduced.

Special-case waste is primarily waste that has limited or no planned disposal alternatives. This waste consists of the following:

- Waste Isolation Pilot Project noncertifiable defense transuranic (TRU) waste

- U.S. Department of Energy-held commercial low-level waste (LLW) [see DOE Order 5820.2A (DOE 1988)] that potentially may be designated as Greater Than Class C (GTCC) under the definition found in Code of Federal Regulation (CFR), Title 10, Part 61.55

- Low-level waste that exceeds site-specific performance assessment limits (DOE 1992).

Special case waste includes high-activity radioactive waste currently stored in hot-cells and retired processing facilities. This waste requires special handling and storage because of the 
HNF-2570, Rev. 0

high radioactive dose rates (i.e., greater than 200 millirem per hour on contact). The SCW includes such items as irradiated research and test materials, dust and debris, hot cell tools and equipment, and failed equipment. Some SCW contains hazardous constituents (DOE 1995a) and is considered MW regulated under RCRA and the Washington Administrative Code (WAC) 173-303, "Dangerous Waste Regulations."

Special case waste currently is located in the 324 Building in the Hanford Site 300 Area. This waste must be removed from the buildings and placed in approved interim storage facilities or disposed of in compliance with the TPA. Removing the waste also is an essential step in facility deactivation.

\subsection{Purpose}

The purpose of the study is to identify the specific characteristics of the 324 Building $\mathrm{SCW}$ associated with the closure actions; identify the packaging, transportation, and storage requirements based on these characteristics; and identify a storage solution.

This document is intended to be a 324 Building Special-Case Waste Assessment in support of the 324 Building closure as outlined in milestone M-89-05. This document is not intended to address all aspects of the M-92 milestones, which include other PNNL buildings, building modifications, project management plans, permit modifications, and others. The latter items will be covered in subsequent documents.

It should be noted that 324 Building closure actions encompass a wider scope of activities than SCW. These are referenced in 324 Building Radiochemical Engineering Cells, High Level Vault, Low Level Vault Associated Areas Closure Plan (DOE/RL-96-73, Rev. 1).

\subsection{Documentation}

Recent changes in organization on the Hanford Site have resulted in contractor changes with a significant expansion in the number of companies participating. Existing documentation controlling the business activities will require time to modify; thus some references may relate to documentation from former contractors. This will remain in place until modifications are complete. 
HNF-2570, Rev. 0

This page intentionally left blank. 
HNF-2570, Rev. 0

\subsection{SPECIAL-CASE WASTE IN SUPPORT OF CLOSURE}

This section defines and describes the 324 Building SCW covered by this assessment, which includes the following.

- 324 B-Cell dispersibles

- $\quad 324$ Vault Tank residual [High-Level Vault (HLV) residuals includes metal filters, strontium filters, TRU ion exchange (IX) column, and the cesium IX column].

\subsection{B-Cell Dispersible Debris, Tank Heels, and Pipe Trench Sludge}

B-Cell SCW can be grouped into three primary waste streams: Dispersible debris on the floor, tank heels, and the airlock pipe trench sludge. Table 2-1 summarizes the data contained in Sections 2.1.1 through 2.1.5.

\begin{tabular}{|l|l|l|l|l|}
\hline \multicolumn{5}{|c|}{ Table 2-1. B-Cell Dispersibles Waste Quick Reference. } \\
\hline \multicolumn{1}{|c|}{ Waste Stream } & \multicolumn{1}{|c|}{ Floor Debris } & \multicolumn{1}{c|}{ Tanks } & Airlock Trench & \multicolumn{1}{c|}{ Total } \\
\hline Volume & $1.3 \mathrm{~m}^{3}\left(47 \mathrm{ft}^{3}\right)$ & $0.5 \mathrm{~m}^{3}\left(19 \mathrm{ft}^{3}\right)$ & $0.4 \mathrm{~m}^{3}\left(15 \mathrm{ft}^{3}\right)$ & $2.3 \mathrm{~m}^{3}\left(81 \mathrm{ft}^{3}\right)$ \\
\hline Curie content & $1,479 \mathrm{Kci}$ & $2,341 \mathrm{Kci}$ & $10 \mathrm{Kci}$ & $3,820 \mathrm{KCi}$ \\
\hline Dangerous waste & Heavy metals & Heavy metals & Heavy metals & N/A \\
\hline Gas generation & Likely & Likely & Likely & N/A \\
\hline Waste classification & $\begin{array}{l}\text { Remote Handled } \\
\text { Mixed TRU }\end{array}$ & $\begin{array}{l}\text { Remote Handled } \\
\text { Mixed TRU }\end{array}$ & $\begin{array}{l}\text { Remote Handled } \\
\text { Mixed TRU }\end{array}$ & N/A \\
\hline N/A = not applicable \\
\hline
\end{tabular}

\subsubsection{B-Cell Floor Debris}

\subsubsection{Detailed Description}

The B-Cell dispersible debris consists of dirt, dust, and process residue collected on the B-Cell floor. Most of the radioactive and hazardous constituents of the dispersible debris were generated during the manufacture of the waste glass logs for the Federal Republic of Germany (FRG). The waste consists of heavy metals, fission products, and trace amounts of spent fuel. Intact fuel and fuel pin cuttings are stored separately in B-Cell and D-Cell. Fuel material is not intentionally allowed to be uncontrolled in the cells. Residues not recognizable as fuel pieces or derived from process fluids should be considered as remote-handled transuranic waste, rather than spent nuclear fuel (SNF). Fuel material will not be sent to the Plutonium Uranium Extraction Facility (PUREX) tunnel. The B-Cell floor debris also includes larger items such as tools and hardware that fell to the floor and became contaminated from the debris. These large 
items will be separated from the dispersible debris at the time of packaging and will be cleaned of dispersible debris and packaged as LLW.

The 324 Building Radiochemical Engineering Cells (REC) B-Cell was used during the 1960 's, 1970's, and 1980's to demonstrate vitrification and other nuclear technology used to process highly radioactive material. During the demonstrations, radioactive material from B-Cell processing tanks was spilled to the floor of the cell. Melter feed solutions and off-gas scrubber solutions were the main materials involved; the predominate radioisotopes were cesium (Cs)-137 and strontium (Sr)-90. The largest of these spills accounts for most of the estimated dispersible activity within B-Cell. The spill, which took place in October 1986, resulted in an estimated $1.271 \mathrm{MCi}(883 \mathrm{KCi}$ of $\mathrm{Cs}-137$ and $338 \mathrm{KCi}$ of $\mathrm{Sr}-90)$ being released to the cell (Holton 1991). Other smaller spills also occurred during the operations, raising the estimated curie content of the dispersible debris in B-Cell to $1.5 \mathrm{MCi}$ (Weaver 1997).

The October 1986 spill occurred under the 1B rack located in the southeast corner of the cell. The B-Cell floor is constructed with a 2 percent slope to the east and a trough along the east wall that drains to a sump located in the northeast corner. The lack of a motive force to move the main spill in a westerly direction leads to the assumption that the highest concentration of radionuclides remains under the $1 \mathrm{~B}$ rack and in the $\mathrm{B}-\mathrm{Cell}$ trough.

Past Dispersible Collection. Approximately 75 percent of the B-Cell floor area was reported to have been 'cleared' of dispersible material (Weaver 1997). The collected material was sorted to remove nondispersible items and the dispersible debris was packaged into sealed engineered waste containers (10-in. schedule 40 pipe). Each container was sampled and characterized. The engineered containers were loaded into liners which then were placed into a steel waste disposal box (SWDB) for shipment to the PUREX Tunnel 2 for storage (PNL 1988). The characterization data revealed that although a reported 75 percent of the floor area had been cleared, only $20.864 \mathrm{KCi}$ associated with the B-Cell dispersibles were shipped to PUREX Tunnel 2. The activity of the collected debris is based on the data provided in the waste manifests for the two SWDB shipments made to PUREX in 1996 (PNNL 1996a, 1996b). This indicates that either the primary deposit has not been picked up or that the actual activity in the cell is much less than the original estimate.

The initial collection activities involved dragging a large heavy square block across the floor to accumulate a pile of debris that was collected using a pneumatic clamshell. This collection method is designed to collect the largest fraction of dispersible material.

Future Dispersible Collection. On October 8, 1997, camera survey of the B-Cell floor showed that approximately $0.6 \mathrm{~cm}(0.25 \mathrm{in}$.) of dispersible dust remains on the floor areas previously cleaned. During removal of the three equipment racks, interim cleanup of accessible dispersible material may be required to control the total inventory of dispersible material on the floors. After all the equipment racks have been removed, future collection operations will include cleaning the remaining 25 percent of the floor areas of the bulk dispersible particulate, then cleaning the entire B-Cell floor area using methods designed to collect the smaller size residual particles. The drag and clamshell method may not collect most of the remaining 
$1,479 \mathrm{KCi}$ from the floor area. Much of the high-activity particulate may remain attached to the cell liner, with a significant source in the B-Cell trench, and will have to be removed by alternative methods.

After the equipment is removed from B-Cell, some of the remaining particulates could be collected using a high-efficiency particulate air (HEPA) filtered vacuum system. This method was demonstrated to be effective during the cleanout of the 324 Building C-Cell based on conversations with building personnel. Vacuuming B-Cell would be a good preparation for final cell cleaning activities. Contaminated material that is firmly attached to the floor and wall surfaces could be removed using a commercially available vacuum blaster or by washing the surfaces.

\subsubsection{Volume.}

The quantity of dispersible waste debris inside B-Cell cannot be precisely measured because B-Cell cannot be directly accessed. The remaining dispersibles, with associated floor debris as currently estimated, is shown in Figure 2-1. Approximately $0.9 \mathrm{~m}^{3}\left(32.5 \mathrm{ft}^{3}\right)$ of the BCell dispersible material was removed, packaged in engineered containers, and sent to the PUREX tunnels for storage in two separate shipments. The waste content description for these shipments are contained in PNL-324-96-012 Manifest 96006 (PNNL 1996a) for the shipment on March 1, 1996, and Waste Manifest 96004 (PNNL 1996b) for the shipment on March 6, 1996.

The cognizant engineer for these shipments to the PUREX tunnels estimated that approximately 75 percent of the B-Cell floor area was cleared of dispersible material before and during the 1996 cleanup operation (Weaver 1997). This originally led to the conclusion that approximately 25 percent or an estimated $10.8 \mathrm{ft}^{3}$ of the dispersible debris remained. To accurately estimate the remaining volume of dispersible debris on the B-Cell floor and estimate the number of containers required for packaging, a visual survey of the B-Cell floor was conducted on October 8,1997 . This survey was conducted using the B-Cell camera to determine the area and height of the dispersible debris piles.

The results of this survey indicated that although 75 percent of the floor is cleaner than the remainder of the cell, approximately $0.6 \mathrm{~cm}(0.25 \mathrm{in}$.) of dispersible dust remains in these cleared areas. The remaining piles of dispersible debris average $5 \mathrm{~cm}$ to $15 \mathrm{~cm}$ (2- to 6-in.) high, with a maximum height of $30 \mathrm{~cm}$ (12 in.) and cover the remaining 25 percent of the floor area. According to these visual observations, approximately $1.3 \mathrm{~m}^{3}\left(47 \mathrm{ft}^{3}\right)$ of dispersible debris remains on the floor of B-Cell. The floor debris will be sifted to eliminate the non-dispersible items. This will reduce the volume of the individual dispersible piles; however this volume reduction is offset by the approximately $0.6 \mathrm{~cm}(0.25 \mathrm{in}$.) of dust left behind on the B-Cell floor areas cleared in 1996 (Wilkinson 1997). 
HNF-2570, Rev. 0

Figure 2-1. B-Cell Floor Sketch

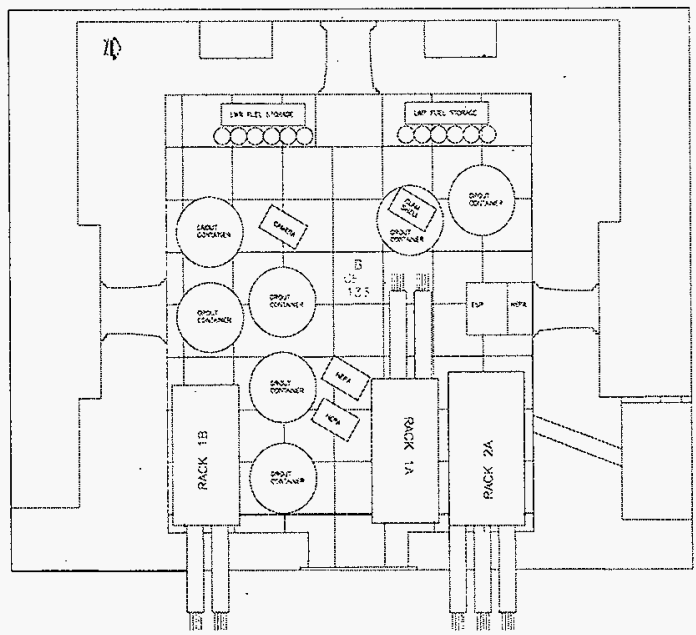




\subsubsection{Radiological Data.}

During routine transfers of radioactive material on October 21,1986 , for the FRG Canister Fabrication Project, approximately $510 \mathrm{~L}$ of concentrated Cs-137/Sr-90 solution leaked to the floor of B-Cell. The estimated radiochemical inventory of the solution was $883 \mathrm{KCi}$ Cs-137 and $388 \mathrm{KCi} \mathrm{Sr}-90$ (Holton, 1991). During B-Cell operations, other releases of radioactive material have occurred to the cell from routine maintenance operations and accidental spills raising the estimated curie content of the dispersible materials in $\mathrm{B}-\mathrm{Cell}$ to $1.5 \mathrm{mCi}$ (Weaver, 1997). The remaining dispersible source term is estimated to be at most $1,479 \mathrm{KCi}$, based on the total curies spilled minus the curies of dispersible waste shipped in 1996 (20.864 $\mathrm{KCi}$.

\subsubsection{Dangerous Waste Constituents.}

Hydrogen Generation. Calculations were performed to estimate the potential hydrogen generation rates from the B-Cell dispersible debris (B-Cell cleanup hydrogen generation in collected dispersible drums) (Weaver 1993). These calculations assumed that the material was initially packaged with a 5-percent water content. For this study, it is assumed that negligible quantities of moisture are present when the packages are loaded, but that the debris may contain organic contaminants because of the presence of plastic and similar materials that have mixed with the debris. The potential hydrogen generation rate is not specifically quantified, but provisions could be made to vent transport/storage containers to prevent hydrogen from accumulating. An analysis of hydrogen generation rates determined that concentrations in the PUREX storage tunnels would pose no safety threat (Owczarski 1995).

Dangerous and Transuranic Waste Constituents. The B-Cell dispersible debris has been sampled several times. PNL-10623, Selection and Evaluation of Alternatives for the Removal of Solid Remote-Handled Mixed Waste from the 324 Building, documented the results of the first known sample of the B-Cell dispersible debris. These results are provided in Table 22 below. Samples were also obtained from ten of the eleven engineered containers of B-Cell dispersible debris that were packaged in 1996 and shipped to PUREX under Manifests 96004 and 96006 (PNNL 1996a and PNNL 1996b). These sample results are provided in Table 2-3.

Table 2-2. B-Cell Debris Sample Results from PNL-10623

\begin{tabular}{|l|c|c|c|c|c|}
\hline Constituent & $\mathrm{Cd}$ & $\mathrm{Cr}$ & $\mathrm{Pb}$ & $\mathrm{Ba}$ & TRU \\
\hline Concentration & $36 \mathrm{ppm}$ & $2500 \mathrm{ppm}$ & $1850 \mathrm{ppm}$ & $874 \mathrm{ppm}$ & 17,600 nano Ci/gm \\
\hline Limit & $1.0 \mathrm{ppm}$ & $5.0 \mathrm{ppm}$ & $5.0 \mathrm{ppm}$ & $100 \mathrm{ppm}$ & 100 nano Ci $/ \mathrm{gm}$ \\
\hline
\end{tabular}

All sample results clearly indicate that the B-Cell dispersibles have transuranic concentrations well above the threshold for classification as TRU. The concentrations of the heavy metals (cadmium, chromium, lead, and barium) show a wide variability. In most cases the concentration of lead exceeded the threshold for designating the waste as a dangerous waste (DW) in accordance with WAC 173-303-090(8)(c), Dangerous Waste Limits." 
In some cases the concentrations of cadmium, chromium, and barium also exceed the DW threshold. Dispersible material in the floor indicated lead and chromium as dangerous components. Melter feed cans contained much higher metal concentrations due to the feed preparation process. It should be noted that the single B-Cell floor sample (Table 2-2) provides a total metals analysis which should be differentiated from a solids/leach analysis (toxic characteristic leaching procedure) found in Table 2-3. Total metals data include metal particulates in the dispersibles.

Table 2-3. B-Cell Dispersible Debris Sample Results from Waste Manifests 96004 and 96006.

\begin{tabular}{|l|c|c|c|c|c|}
\hline Constituent & Cadmium & Chromium & Lead & Barium & Transuranic \\
\hline Concentration & $\mathrm{ppm}$ & $\mathrm{ppm}$ & $\mathrm{ppm}$ & $\mathrm{ppm}$ & nano Ci/gm \\
\hline EC-14 & 0.35 & 0.09 & 0.09 & 0.64 & 23,100 \\
\hline EC-15 & $<.02$ & $<.03$ & $<.08$ & $<.01$ & 10,500 \\
\hline EC-16 & 1.0 & 0.87 & 34.6 & 1.8 & 11,300 \\
\hline EC-17 & 0.73 & 1.1 & 3.57 & 1.04 & 12,100 \\
\hline EC-19 & $<.02$ & $<.03$ & $<.08$ & $<.01$ & 19,600 \\
\hline EC-21 & 0.09 & 0.35 & 13 & 1.5 & 15,100 \\
\hline EC-22 & 0.59 & 0.27 & 27.9 & 1.45 & 18,700 \\
\hline EC-23 & 0.07 & 0.03 & 13.7 & 1.03 & 32,000 \\
\hline EC-24 & 0.37 & 6.3 & 34.5 & 0.97 & 3,530 \\
\hline EC-25 & 0.06 & 0.03 & 4.95 & 1.06 & 30,000 \\
\hline Average & 0.71 & 1.63 & 24.11 & 1.34 & 17,600 \\
\hline Limit* & 1.0 & 5.0 & 5.0 & 100 & 100 \\
\hline
\end{tabular}

*TRU limit---DOE order 5820.2A, II.3.a.(2)

*Dangerous Waste limits---WAC 173-303-090(8)(c)

\subsubsection{Waste Classification.}

The sampling results summarized in Section 2.1.1.3 are not necessarily representative of the remaining dispersible debris because of the heterogeneous characteristics of the waste. However, based on these measurement results, the B-Cell debris will be classified as mixed TRU waste.

The waste category and classification per Waste Manifest 96006 were Greater-ThanCategory 3 (GTC3) and mixed TRU, respectively, with a total fission/activation nuclide activity of $15.586 \mathrm{KCi}$. The waste category and classification per Waste Manifest 96004 also were GTC3 and mixed TRU, respectively, with a total fission/activation nuclide activity of $5.278 \mathrm{KCi}$. 
The larger items, such as tools and hardware, that have fallen to the floor in B-Cell will be cleaned of dispersible debris and disposed of as LLW.

\subsubsection{B-Cell Tank Heels}

\subsubsection{Detailed Description.}

Three equipment racks, numbered $1 \mathrm{~A}, 1 \mathrm{~B}$ and $2 \mathrm{~A}$, are located along the B-Cell east wall (see Figure 2-1). Each rack has two tanks that were used for different processes. The current disposal plan for the racks, structural components, and tanks is to cut them into manageable-size pieces for shipment as LLW to the Hanford Site burial grounds. The process tanks with heel residues will be packaged for disposition as mixed TRU as the tanks are sectioned. Cutting the racks and tanks will create some additional dispersible waste material in addition to the tank heel material, but the volume generated will be much less than the $1.3 \mathrm{~m}^{3}\left(47 \mathrm{ft}^{3}\right)$ already present. The following provides a description of the B-Cell rack tanks. Table 2-4 identifies the reference drawings for each tank.

- Rack 1A houses Tank 113 and Tank 115. Tank 113 was used as an evaporator vessel and is assumed to have an $8 \mathrm{~cm}$ (3-in.) heel. Its reboiler is assumed to be full of sludge. Tank 115 was used as an acid fractionator reboiler and is assumed to have an $8 \mathrm{~cm}(3-\mathrm{in}$.) heel.

- $\quad$ Rack 1B houses Tank 112 and Tank 114. Tank 112 was used for HLV liquid processing and is assumed to have an $8 \mathrm{~cm}$ (3-in.) tank heel. Tank 114 was used for the FRG as a melter feed tank supporting the waste vitrification process and will contain heavy metals. This tank is assumed to have an $8 \mathrm{~cm}$ (3-in.) heel.

- Rack 2A houses Tank 116 and Tank 118 that were used to support the off-gas system and condenser system. These tanks are assumed to have an $8 \mathrm{~cm}$ (3-in.) heel.

\begin{tabular}{|l|l|}
\hline \multicolumn{2}{|c|}{ Table 2-4. Reference Drawings for B-Cell Tanks. } \\
\hline \multicolumn{1}{|c|}{ Tank Number } & \multicolumn{1}{c|}{ Drawing Number } \\
\hline Tank 112 & H-3-21007, H-3-21018 \\
\hline Tank 113 & H-3-21008 \\
\hline Tank 114 & H-3-21007, H-3-21018 \\
\hline Tank 115 & H-3-21010 \\
\hline Tank 116 & H-3-21011 \\
\hline Tank 118 & H-3-21013, H-3-21018, H-3-21017 \\
\hline
\end{tabular}




\subsubsection{Volume.}

Using the B-Cell heel calibration logs for the tank volume versus tank level and the assumed tank heel levels, the volumes of the tank heel waste were calculated to be as shown in Table 2-5.

\begin{tabular}{|l|l|}
\hline \multicolumn{2}{|c|}{ Table 2-5. B-Cell Tank Heel Waste Volume. } \\
\hline \multicolumn{1}{|c|}{ Tank } & \multicolumn{1}{c|}{ Volume $\left[\mathrm{m}^{3}\left(\mathrm{ft}^{3}\right)\right]$} \\
\hline Tank 112 & $0.04 \mathrm{~m}^{3}\left(1.5 \mathrm{ft}^{3}\right)$ \\
\hline Tank 113 & $0.3 \mathrm{~m}^{3}\left(12 \mathrm{ft}^{3}\right)$ \\
\hline Tank 114 & $0.04 \mathrm{~m}^{3}\left(1.5 \mathrm{ft}^{3}\right)$ \\
\hline Tank 115 & $0.03 \mathrm{~m}^{3}\left(1.0 \mathrm{ft}^{3}\right)$ \\
\hline Tank 116 & $0.035 \mathrm{~m}^{3}\left(1.25 \mathrm{ft}^{3}\right)$ \\
\hline Tank 118 & $0.04 \mathrm{~m}^{3}\left(1.5 \mathrm{ft}^{3}\right)$ \\
\hline \multicolumn{2}{|c|}{ Total } \\
\hline
\end{tabular}

The tank heels cannot effectively be removed from the internal surfaces of the tanks. Chemical cleanup would be difficult to accomplish because the piping connections have not been as built and the process lines could not be properly tested for integrity. Mechanical scraping would not remove the entire waste heel residue and the tanks would remain classified as $\mathrm{MW}$ and would have to be packaged and disposed of in a manner similar to the heel residues. Because of the difficulties in removing the heel residues and because the tanks may have to be sectioned and disposed of as MW even if the heel were removed, best disposition option for the B-Cell tanks is to section them with the heel inside. The tank sections would then be packaged and disposed of as mixed TRU. The total volume of the tank segments and associated equipment is estimated to be $9.9 \mathrm{~m}^{3}\left(350 \mathrm{ft}^{3}\right)$ (based on the total tank volumes).

\subsubsection{Radiological Data.}

The activity of the heel remaining in Tank 113 was calculated to be $689 \mathrm{KCi}$ of Cs-137 and $811 \mathrm{KCi}$ of Sr-90 using data from past process inventories (O'Neill, 1997). The activity of heel concentrations of Tank 112, Tank 114, Tank 115, Tank 116, and Tank 118 were calculated using the same curie-per-cubic foot concentration as identified for Tank 113 (see Table 2-6). 


\begin{tabular}{|c|c|c|c|}
\hline \multicolumn{4}{|c|}{ Table 2-6. Tank Heel Estimated Curie Content*. } \\
\hline Tank & Cesium & Strontium & Total \\
\hline Tank 112 & $86 \mathrm{KCi}$ & $101.5 \mathrm{KCi}$ & $187.5 \mathrm{Kci}$ \\
\hline Tank 113 & $689 \mathrm{KCi}$ & $811 \mathrm{KCi}$ & $1500 \mathrm{Kci}$ \\
\hline Tank 114 & $86 \mathrm{KCi}$ & $101.5 \mathrm{KCi}$ & $187.5 \mathrm{Kci}$ \\
\hline Tank 115 & $57.5 \mathrm{KCi}$ & $67.6 \overline{\mathrm{KCi}}$ & $125.1 \mathrm{Kci}$ \\
\hline Tank 116 & $71.8 \mathrm{KCi}$ & $84.5 \mathrm{KCi}$ & $156.3 \mathrm{Kci}$ \\
\hline Tank 118 & $86 \mathrm{Kci}$ & $101.5 \mathrm{KCi}$ & $187.5 \mathrm{Kci}$ \\
\hline Total & $1076.3 \mathrm{Kci}$ & $1267.6 \mathrm{Kci}$ & $2343.9 \mathrm{KCi}$ \\
\hline
\end{tabular}

*The above curie estimates are derived for planning purposes only.

\subsubsection{Dangerous Waste Constituents.}

The B-Cell tanks are expected to contain heavy metals in concentrations the same as or higher than were observed in the samples obtained from the B-Cell dispersible debris shipped in 1996. Based on the cell waste shipped in 1996, the hazardous waste constituents and their respective waste codes will be lead (D008), possibly barium (D005), cadmium (D006), and chromium (D007).

\subsubsection{Waste Classification.}

The B-Cell tank heels are expected to contain TRU and DW in the same as or higher concentrations than were observed in the samples from the 1996 waste shipments. Because these TRU and DW concentrations exceed the minimums for classification as TRU and DW, the tank heel waste is considered to be mixed TRU for purposes of this study. If the tank segments with the heel residues inside are to be packaged and disposed of together, the waste matrix would be designated as DW or extremely hazardous waste assuming that the concentration of lead and other heavy metals in the heels exceeds the DW or extremely hazardous waste thresholds in WAC 173-303-090. The TRU classification may not apply to the tank segments with heel residue because the weight of the metal can be added to calculate the equivalent nano curies per gram of waste.

\subsubsection{REC Pipe Trench Sludge}

\subsubsection{Detailed Description.}

The REC airlock floors slope to a hot pipe trench along the west side for collecting liquids, such as those resulting from decontamination washes. These washes also would contain metal shavings or particles and other debris (e.g., dirt and dust along with resins) from cutting operations performed in these areas and residues from containers removed from the hot cells. After years of use, the trench is assumed to have collected solids from the decontamination washes, possibly forming a sludge-like material. 
HNF-2570, Rev. 0

Review of the facility area drawings by the facility operations and engineering personnel showed that drip pans are positioned between the piping and the trench floor. These drip pans would need to be removed to allow direct viewing and also inhibit sampling of the trench sludge for characterization. The trench has an approximately $0.6 \mathrm{~m} \mathrm{(2-ft)} \mathrm{slope} \mathrm{toward} \mathrm{north} \mathrm{corner} \mathrm{for}$ drainage. Because of this slope, the sludge is expected to have accumulated mostly in the sump region starting at the trench midpoint.

\subsubsection{Volume.}

The depth of sludge assumed to have accumulated in the pipe trench is estimated to be $8 \mathrm{~cm}$ ( 3 in.). Using this depth and the profile of the trench, the volume of sludge was calculated to be $0.4 \mathrm{~m}^{3}\left(15 \mathrm{ft}^{3}\right)$. Quantitative data are not available to verify this amount, which should be considered to be a conservative (higher than anticipated) value.

\subsubsection{Radiological Data.}

Because the liquid waste generated in the airlock that would have accumulated in the trench came from handling/decontamination of B-Cell equipment, the trench is assumed to have the same activity levels as B-Cell dispersibles. Based on the curie content in the dispersible waste shipped in 1996, the curie content in $0.4 \mathrm{~m}^{3}\left(15 \mathrm{ft}^{3}\right)$ of waste in the trench will be $10 \mathrm{KCi}$.

\subsubsection{Dangerous Waste Constituents.}

The trench is assumed to have the same dangerous waste constituents as the B-Cell dispersibles. Based on the cell waste shipped in 1996, the hazardous waste constituents and their respective waste codes will be lead (D008), and possibly barium (D005), cadmium (D006), and chromium (D007). Waste code (WT01) for toxic waste also would apply.

\subsubsection{Waste Classification.}

The composition and quantity of the sludge at this time is unknown because the drip pan is in place.

Because the sludge is a result of the decontamination washing of the REC airlock and equipment removed from the B-Cell, its composition is assumed to resemble that of the B-Cell debris that was classified as mixed TRU. Along with the radioactive constituents, the sludge may contain traces of spent fuel and other heavy metals. Identifiable spent fuel is separate from SCW and is not sent to the PUREX tunnel. 
HNF-2570, Rev. 0

\subsection{High-Level Vault Tank Filters/Columns}

\subsubsection{Detailed Description}

The 324 Building HLV Interim Removal Action Project was established to address TPA milestone M-89-01, "Complete Removal of the 324 Building HLV Tank MW (e.g., Tank 104, Tank 105, Tank 107) with the Exception of Residues Which May Remain Following Flushing and Draining to the Extent Possible." This equipment consisted of 20 metal filters, five strontium filters, one TRU column and nine IX columns. This equipment was used in the treatment process along with process tanks for neutralization (Tank 112), metal filtering of feed, carbonate precipitation, IX feed, and evaporation. Effluent evaporation was not required, effluent solution was discharged directly to the 340 Building for loadout to the 200 Area tank farms.

Three ( $\mathrm{Sr}-1, \mathrm{Sr}-2$, and $\mathrm{Sr}-3$ ) of the five strontium filters were shipped to the $325 \mathrm{Building}$ on January 26, 1998, for use in medical isotopes. Filters $\mathrm{Sr}-1, \mathrm{Sr}-2$ and $\mathrm{Sr}-3$ containing Strontium Carbonate were transferred to the 325 Building for an endpoint use as a Yttrium 90 generator. This high energy beta emitter will be used for cancer treatment in conjunction with other compounds. The remaining two filters ( $\mathrm{Sr}-4$ and $\mathrm{Sr}-5$ ) will follow the same path forward as the metal filters described in this section, including packaging and storage requirements.

The TRU filter was used to remove any residual alpha from the HLV feed before the feed was sent to the cesium IX columns.

The nine cesium IX columns were transferred into the D-Cell for separation. Ion Exchange Column 4 was not placed in service according to the process logs and records for HLV operations. Ion Exchange Column 9 was used only for polishing/rinsing and did not accumulate significant radionuclides.

The operation history of filters in D-Cell is documented in the HLV Operations Log. Pertinent information includes transfers to D-Cell from B-Cell, including batch information, filter or column change outs, location and identification of samples taken, and any abnormal occurrences (spills, leaks, alarms, equipment failure, etc.). Table 2-7 summarizes the data contained in the subsequent sections.

\subsubsection{Volume}

The strontium filter dimensions are $7.3 \mathrm{~cm}$ (2.875 in.) in diameter, by $31.75 \mathrm{~cm}$ (12.5 in.) length, yielding a volume of $0.0014 \mathrm{~m}^{3}\left(0.05 \mathrm{ft}^{3}\right)$ each. The total volume for the 5 strontium filters is estimated to be $0.006 \mathrm{~m}^{3}\left(0.22 \mathrm{ft}^{3}\right)$. Only Sr-4 and $\mathrm{Sr}-5$ are waste.

The cesium IX column dimensions are $21.9 \mathrm{~cm}$ ( $8.625 \mathrm{in}$.) diameter by $61 \mathrm{~cm}(24.0 \mathrm{in}$. long, yielding a volume of $0.023 \mathrm{~m}^{3}\left(0.81 \mathrm{ft}^{3}\right)$ each. The total volume of the $\mathrm{LX}$ ion exchange columns is estimated to be $0.121 \mathrm{~m}^{3}\left(7.3 \mathrm{ft}^{3}\right)$. 


\begin{tabular}{|l|l|l|l|l|}
\hline \multicolumn{5}{|c|}{ Table 2-7. HLV Residual Waste Stream Quick Reference. } \\
\hline $\begin{array}{l}\text { Waste Stream } \\
\text { Component }\end{array}$ & $\begin{array}{c}\text { Strontium } \\
\text { Filter }\end{array}$ & $\begin{array}{c}\text { Cesium IX } \\
\text { Column }\end{array}$ & \multicolumn{1}{|c|}{ Metal Filters } & TRU Filter \\
\hline Total volume & $0.25 \mathrm{ft}^{3}$ & $7.65 \mathrm{ft}^{3}$ & $12 \mathrm{ft}^{3}$ & $0.58 \mathrm{ft}^{3}$ \\
\hline $\begin{array}{l}\text { Total curie } \\
\text { content }\end{array}$ & $9.669 \mathrm{KCi}$ & $30.378 \mathrm{KCi}$ & $\begin{array}{l}20,760 \mathrm{Ci}\left({ }^{90} \mathrm{Sr}\right) \\
2,150 \mathrm{Ci}\left({ }^{137} \mathrm{Cs}\right) \\
799 \mathrm{Ci}(\text { (alpha isotopes) }\end{array}$ & $2,067 \mathrm{Ci}$ \\
\hline Dose rate & High & High & High & High \\
\hline $\begin{array}{l}\text { Dangerous } \\
\text { waste* }\end{array}$ & $\begin{array}{l}\text { Chromium, } \\
\text { cadmium* }\end{array}$ & None & $\begin{array}{l}\text { Lead, barium, chromium, } \\
\text { cadmium }\end{array}$ & Chromium \\
\hline $\begin{array}{l}\text { Gas generation } \\
\text { Yes (Sr-4 } \\
\text { and Sr-5 } \\
\text { only) }\end{array}$ & No & Yes & Yes \\
\hline $\begin{array}{l}\text { Waste } \\
\text { classification* }\end{array}$ & $\begin{array}{l}\text { Mixed TRU } \\
\text { for Sr-4 and } \\
\text { Sr-5 }\end{array}$ & $\begin{array}{l}\text { Class C } \\
\text { LLW }\end{array}$ & Mixed TRU & Mixed TRU \\
\hline *Refer to Appendix A for details of sample analysis results. & \\
\hline
\end{tabular}

The metal filters are $21.9 \mathrm{~cm}(8.625 \mathrm{in}$.) in diameter by $44.5 \mathrm{~cm}(17.5 \mathrm{in}$.) high, yielding a volume of $0.016 \mathrm{~m}^{3}\left(0.59 \mathrm{ft}^{3}\right)$ each. The total volume of the 20 metal filters is $0.33 \mathrm{~m}^{3} \cdot\left(11.8 \mathrm{ft}^{3}\right)$.

The TRU filter dimensions are $21.9 \mathrm{~cm}$ ( $8.625 \mathrm{in}$.) in diameter by $40.6 \mathrm{~cm}$ ( $16.0 \mathrm{in}$.) long, yielding a volume of $0.015 \mathrm{~m}^{3}\left(0.54 \mathrm{ft}^{3}\right)$ each.

\subsubsection{Radiological Data}

Strontium Filters - Strontium filter activity data sheets have not been located. A summary of assumptions and approximations for calculating the contents of the strontium filters from the HLV process was compiled by Gary Sevigny of PNNL, documenting the total activity level in all five strontium filters to be $9.669 \mathrm{KCi}$ with $3.887 \mathrm{KCi}$ in Filter 2.

Cesium Ion Exchange Columns. Cesium ion exchange column data sheets have not been located. A summary of assumptions and approximations for calculating the content of the cesium ion exchange columns from the HLV process was compiled by Gary Sevigny of PNNL, documenting the total activity for all nine ion exchange columns to be $30.378 \mathrm{KCi}$ and 5.383 KCi maximum for IX Column 2. Because the cesium IX columns were downstream of the TRU filters, the transuranic waste concentrations in these columns are assumed to be negligible (TRU constituents below $100 \mathrm{nCi} / \mathrm{g}$ ). This assumption is supported by the process feed solution sample results. 
Metal Filters. Activity levels for the 20 metal filters are documented on HLV Data Sheet 3, the Metal Filter Loading Log (9/9/96 to 10/5/96), and HLV operating Logbook BNW-56293. No activity level for the tank that used Metal Filter 14 is available. A summary of assumptions and approximations for calculating the content of the metal filters from the HLV process was compiled by Gary Sevigny of PNNL, documenting the activities of each metal filter as derived from data sheets and calculation. The total dose equivalent for the metal filters is estimated to be $646 \mathrm{Ci}$. Actual curies are $20,764 \mathrm{Ci}$ of ${ }^{90} \mathrm{Sr}, 2,151 \mathrm{Ci}$ of ${ }^{137} \mathrm{Cs}$, and $749 \mathrm{Ci}$ of alpha isotopes.

TRU Filter. No TRU activity data sheets have been located for this filter. A summary of assumptions and approximations for calculating the contents of the TRU filter from the HLV process was compiled by Gary Sevigny of PNNL, estimating the total activity of the TRU filter to be $2,067 \mathrm{Ci}$, including $2,032 \mathrm{Ci}$ of $\mathrm{Sr}-90$.

\subsubsection{Dangerous Waste Constituents}

The HLV tank waste was sampled in 1990. These samples and analyses were used in DOE/RL-96-76, Rev. 1, The 324 Building Radiochemical Engineering Cells, High-Level Vault, Low-Level Vault, and Associated Items Closure Plan (DOE/RL 1998) to designate the tank waste as DW. Section 4.2 of the closure plan discusses the waste designations. Because the filters processed the feed solution from the HLV tanks, the waste designation should be the same. This conclusion is supported by sample results from the process feed solutions into and out of the filters [refer to Waste Analysis Plan for the 324 Building HLV Interim Action Removal Project (PNNL 1996d)]. The cesium IX columns were downstream of the filters. Because the filters would be expected to remove the heavy metals, the cesium IX columns would not be expected to contain DW. This assumption is supported by core samples obtained from the cesium DX columns. Six core samples from the cesium $\mathrm{DX}$ columns (IX-1, 2,3,5, and 7) were evaluated by PNNL from January 1997 through March 1997 (O'Neill 1997). The Toxicity Characteristics Leaching Procedure and Inductive Coupled Plasma/Mass Spectrometry results for these columns were provided. The core samples were obtained only for measuring the presence of hazardous and heavy metals and determining the $\mathrm{pH}$ value of the solution. No DW was found to be present in the six core samples. Cesium concentrations from the leachate test were $50 \mathrm{mg} / \mathrm{mL}$.

Appendix $\mathrm{C}$ summarizes the analytical results from the process feed samples and core samples.

\subsubsection{Waste Classification}

The metal filters are tentatively categorized as mixed TRU based on tank rinsate analysis showing TRU levels at $110 \mathrm{nCi} / \mathrm{g}$ and the presence of hazardous constituents. Refer to Appendix A for sample results.

The TRU column is categorized the same as the metal filters (mixed TRU) based on the sample results (refer to Appendix A).

Three strontium filters (Sr-1, Sr-2, and $\mathrm{Sr}-3$ ) are designated for beneficial use for medical isotopes. The sample results from the process feed solutions documented in the Summary of Assumptions/Approximations for Calculating the Contents of Metal Filers, Strontium Filters, 
HNF-2570, Rev. 0

and Ion-Exchange Columns from HLV Process (O'Neill. 1997), indicate no TRU or DW. The strontium filters not used for medical isotopes should be classified as Class C LLW based on the curie content and volume of each filter.

The cesium IX columns do not contain any DW or TRU. (Refer to Appendix A for core sample results). Based on the curie content and volume, the cesium IX columns will be designated as Class C LLW.

Additional SCW may be generated when the REC, HLV, and LLV are cleaned and decontaminated. This material will be in a form similar to the existing High Level Vault waste and may be from either the D-Cell waste treatment system or skid based treatment systems located elsewhere.

\subsection{Other Waste Streams}

During the deactivation and cleanout operations for the 324 Building additional waste similar to that included in this study may be generated. The types of waste anticipated to be generated include residual waste in ducts, tanks, piping, and secondary waste coming from deactivation operations such as filters, and ion exchange media. These waste types must be characterized, classified, and handled in accordance with approved deactivation and clean-up plans, site standards, and closure plans.

Since the contamination being removed from the surfaces of rooms, piping and vessels is very similar to bulk material that has been characterized and removed, it is anticipated that the waste types generated will be SCW. The packaging and form for this material maybe different from the original high level solid material previously removed because the removal methods will be different.

For example, the exhaust ducting from B-Cell is reported to contain $30 \mathrm{KCi}$ of radioactive holdup (PNNL 1996c). The composition of most of this inventory should parallel that of the B-Cell inventory and should include Cs-137 and Sr-90. Because the exhaust ducting is relatively inaccessible and the system will be used until B-Cell is deactivated, the residual must remain in place. In addition, a general area dose rate of $60 \mathrm{rad} / \mathrm{hr}$ has been measured in the HLV. This is expected to be from an undetermined amount of solids left by evaporation of liquid waste heels left in the four vault tanks after steam jetting. Deactivation planning must take into account disposition of the exhaust duct holdup and tank residuals. 
HNF-2570, Rev. 0

\subsection{Previously Dispositioned 324 SCW In PUREX Tunnel}

Based on the PNNL study (PNNL 1995) SCW from a number of 324 Building SCW streams was packaged and shipped to the PUREX tunnels in 1996 where it is being stored. The waste streams include approximately $0.96 \mathrm{~m}^{3}\left(34 \mathrm{ft}^{3}\right)$ of B-Cell dispersible debris and $0.17 \mathrm{~m}^{3}$ $\left(6 \mathrm{ft}^{3}\right)$ of 324 Building B-Cell dried melter feed in engineered containers. No additional material of this kind has been found. Also included in these shipments were liquid metal seal-low temperature alloy and oil absorption material, HEPA filters, and high-activity metals and refractory bricks. Like the dried melter feed, this material has been removed from the 324 Building and put into storage in the PUREX tunnels. 
HNF-2570, Rev. 0

This page intentionally left blank. 


\subsection{REQUIREMENTS ANALYSIS}

\subsection{Packaging Requirements}

General packaging requirements for the transportation and storage of radioactive waste address three safety functions: containment, shielding, and subcriticality. The packaging requirements for transportation, a transient operation, can be more restrictive because the transportation environment includes dynamic stresses not present during storage. In contrast, storage requirements must consider the safety of the facility and the life of the package over the long term. These basic requirements apply to both onsite and offsite transportation of radioactive materials. For offsite transportation, packaging requirements and approvals are enforced by the U.S. Department of Transportation DOT and the U.S. Nuclear Regulatory Commission (NRC). Typically, radioactive material packagings that are approved or certified by these entities for transporting high-activity materials are costly and complex. However, the use of packaging systems that have been approved locally by RL or the appropriate contractor organizations allows greater flexibility onsite.

Radioactive material packaging systems used exclusively on the Hanford Site (onsite packaging) are analyzed and engineered to provide thermal dissipation, shielding, containment, and assurance of subcriticality. The certified packaging required by the U.S. Department of Transportation for shipping radioactive material on public roadways require extensive and costly testing and documentation. To limit cost of transporting radioactive materials within the Hanford Site boundaries, onsite packaging is analyzed and approved in accordance with an established transportation safety program. On site packaging is approved for use only on Hanford roadways subject to the controls specified in the Safety Analysis Report for Packaging (SARP) or Safety Evaluation for Packaging (SEP). Hanford Site road access is restricted during such shipments. Onsite shipping is referenced in HNF-PRO-154 and is regulated by 49 CFR 263.

The SCW streams are expected to include six waste categories: LLW, LLW Class C, GTC3 LLW, GTC3 low-level mixed waste (LLMW), TRU, and mixed TRU. Because the

packaging and characterization process are assumed to limit the fissile isotope content ${ }^{233} \mathrm{U}$, ${ }^{235} \mathrm{U},{ }^{238} \mathrm{Pu},{ }^{239} \mathrm{Pu}$, and ${ }^{241} \mathrm{Pu}$ ) of each package to fissile exempted limits (49 CFR 173), the issue of criticality does not require evaluation or special packaging controls. The waste categories do not specifically dictate the packaging requirements for transportation. The necessary packaging features to control dose rates and contain the material are determined by the activity levels and the physical and chemical form of the payload. Therefore, no individual requirements exist for transporting each waste type. However, prior to packaging and shipment wastes will be characterized (including fissile content) to ensure appropriate packaging and transportation requirements are implemented.

Containers used for shipping, storage, and disposal of waste must be in good condition with no visible flaws that could compromise integrity or performance. The packaging material should be resistant to degradation by microbiological action, moisture, radiation effects, or chemical reactions with the waste. 


\subsubsection{Central Waste Complex/Burial Grounds Packaging Requirements}

At least two containment barriers to prevent release of contamination are required. Exceptions are listed in the Hanford Site Solid Waste Acceptance Criteria, WHC-EP-0063-4 (Willis 1993). Packages must be able to withstand the weight of two layers of $454 \mathrm{~kg}$ (1000-lb) 55 -gallon drums stacked on top. All packages shall be fabricated of metal or shall be made fire retardant.

Waste packages intended for disposal (burial) shall not contain free liquids in excess of 1 percent of the waste volume. The internal void space of the package shall not exceed 10 percent of the total internal volume. Waste packages sent to the Central Waste Complex (CWC) for storage shall not exceed $100 \mathrm{mrem} / \mathrm{hr}$ at a distance of $30 \mathrm{~cm}$ or $200 \mathrm{mrem} / \mathrm{hr}$ on contact. Specific criteria for each waste type are provided in Sections 4.1.1.1 through 4.1.1.3.

\subsubsection{Transuranic-Mixed and Transuranic Non-Mixed.}

Transuranic waste is required to meet the TRU waste criteria specified in WHC-EP-00634, Chapter 5.0, "Transuranic Waste" (Willis 1993).

- The waste shall be assayed or otherwise evaluated to determine the kind and quantity of TRU radionuclides. The hazardous waste components shall be estimated or analyzed.

- Total liquid in waste containers shall not exceed 1 percent by volume.

- The TRU waste shall not have RCRA characteristics of ignitability (D001), corrosivity (D002), or reactivity (D003).

- The waste packaging acceptable for TRU and mixed TRU are the standard 55-gallon drum meeting performance standards of UN1A2, the standard waste box (SWB) ( $4 \times 4 \times 8 \mathrm{ft}$ box) and 55-gallon drums overpacked in a SWB. Transuranic waste in packagings other than the 55-gallon drums or the SWB can be accepted if the deviation is adequately documented in the Waste Certification Summary.

- The fissile or fissionable radionuclide content shall be no greater than 200 fissile gram equivalent of ${ }^{239} \mathrm{Pu}$ for the 55-gallon drum or 325 fissile gram equivalent for the SWB.

- Transuranic waste containers shall not exceed $100 \mathrm{mrem} / \mathrm{hr}$ dose rate at the surface.

- Weight limits are as follows:

- $\quad 454 \mathrm{~kg}(1,000 \mathrm{lb})$ per 55-gallon drum 
- $\quad 658 \mathrm{~kg}(1,450 \mathrm{lb})$ per drum overpacked in a SWB

- $\quad 18184 \mathrm{~kg}(4,000 \mathrm{lb})$ per SWB.

\subsubsection{Low-Level Waste GTC3.}

The packaging requirements for GTC3 LLW are virtually identical to those required for TRU or MW, although the material is not required to be packaged in drums or the SWB.

\subsubsection{Low Level Waste.}

The packaging, transportation, and disposal of LLW are routine activities. The packaging requirements are minimal but the dose rate limits apply.

\subsubsection{Canyon Facility Packaging Requirements}

The T Plant Canyon packaging requirements for waste packages are assumed to be similar to the packaging requirements of the $\mathrm{CWC}$, but would require analysis on individual containers.

\subsubsection{PUREX Tunnel Packaging Requirements}

For storage in the PUREX Tunnel, waste acceptance criteria, including packaging requirements, are proposed by the waste generator and approved on a case-by-case basis. Introduction of waste material to the tunnel will require preparation of tunnel waste acceptance criteria. This document has not been prepared at the time of writing. In general, packaging requirements would include standards for dose rates (if contact handled), containment barriers, thermal dissipation and criticality control. Packaging system performance is a factor in determining the inventory at risk in the facility through the safety analysis process.

\subsubsection{Potentially Gas-Generating Waste}

Several waste streams contain organic components that may result in the generation of hydrogen gas by radiolytic mechanisms. These materials require packaging configurations that allow the gas to be vented, usually through a Nucfil filter.

\subsubsection{Packaging Availability}

Table 3-1 lists the containers described in this document along with their nominal volumes and shielding thicknesses. Cost data also are included. 


\subsection{Transportation Requirements}

This section provides regulatory and administrative requirements associated with the various modes of transportation anticipated or available.

\subsubsection{Shipment of Casks by Truck}

Shipment of casks by truck would be controlled by the safety documentation that applies to the packaging system. The onsite packaging safety documentation (SARP or SEP) specifies the transportation requirements for each packaging system. These requirements and administrative controls may address the type of equipment used (i.e., tractor-trailer configurations, special lifting requirements, special radiological controls for transport, road closures, speed limits, times of travel, special routing, inclement weather restrictions, and engineered tie down requirements).

\subsubsection{Shipment of Boxes by Truck}

Shipping boxes or special packages by truck has requirements similar to those discussed in Section 3.2.1. Because boxes and other containers typically provide less shielding, radiological controls associated with the shipment of these types of packages may be more restrictive.

\subsection{Storage Requirements}

\subsubsection{Physical Constraints}

Physical constraints are specified in the facility requirements for storage of radioactive and MW.

\subsubsection{Permit Conditions}

All Hanford Site facilities that treat, store, or dispose of dangerous waste are identified in DOE/RL-88-21, Hanford Site Facility Dangerous Waste Part A Permit Application, (DOE-RL 1988). This Part A Permit Application lists the TSD facilities that require a Part B permit to continue to operate and the facilities that will be allowed to continue to operate under Interim Status. For facilities that have approved Part B permits (i.e., Final Status), changes in quantity or method may require permit revisions. In the case of the PUREX tunnel, if the storage capacity is increased or new waste categories are introduced, then permit revisions are required per WAC 173-303-830(3). 
Table 3-1. Packaging Availability.

\begin{tabular}{|c|c|c|c|c|c|c|}
\hline Packaging & Availability & $\begin{array}{l}\text { Vol } \\
\left(\mathrm{ft}^{3}\right)\end{array}$ & Shielding & Venting & Cost/unit & Reference \\
\hline GNS-12 cask & 2 at Hanford & $17.7^{\circ}$ & 4 in. lead & optional & $\begin{array}{l}\text { Modification for venting } \\
\text { fixture: } \$ 25,000 \\
\text { New basket: } \$ 25,000- \\
\$ 40,000 \\
\text { SARP change: } \$ 50,000\end{array}$ & $\begin{array}{l}\text { HNF-SD-TP-SARP-022, Safety } \\
\text { Analysis Report for Packaging } \\
\text { (Onsite) for the GNS-12 Packaging, } \\
\text { Rust Federal Services Inc., Northwest } \\
\text { Operations for Fluor Daniel } \\
\text { Hanford, Inc., Richland, Washington. }\end{array}$ \\
\hline CASTOR cask & Purchase & 27.6 & lead/iron & optional & $\$ 290 \mathrm{~K}$ & $\begin{array}{l}\text { HNF-SD-TP-SARP-021, Safety } \\
\text { Analysis Report for Packaging } \\
\text { (Onsite) CASTOR GSF Cask, Rust } \\
\text { Federal Services Inc., Northwest } \\
\text { Operations for Fluor Daniel Hanford, } \\
\text { Inc., Richland, Washington }\end{array}$ \\
\hline $\begin{array}{l}221 / 2 \text { ton box } \\
\text { SWDB }\end{array}$ & $\begin{array}{l}1 \text { box } \\
\text { [Liners can } \\
\text { be } \\
\text { purchased] }\end{array}$ & 70.1 & 9 in. steel & yes & $\begin{array}{l}\text { Fabrication of new liners: } \\
\$ 10,000 \text { each } \\
\text { Cost of complete SWDB with } \\
\text { liner } \$ 100,000 \text {, }\end{array}$ & $\begin{array}{l}\text { PNNL, 1988, Safety Analysis Report } \\
\text { (SAR) for the Steel Waste Package, } \\
\text { PNL-MA-651, Rev. 1, Battelle Pacific } \\
\text { Northwest Laboratory, Richland, } \\
\text { Washington. }\end{array}$ \\
\hline $\begin{array}{l}\text { Concrete Burial } \\
\text { Boxes }\end{array}$ & 6 at B Plant & 1440 & $\begin{array}{l}4 \text { in. } \\
\text { concrete }\end{array}$ & optional & $\begin{array}{l}\text { Modification for lifting: } \\
\$ 75,000 \text { each }\end{array}$ & $\begin{array}{l}\text { WHC-SD-TP-SARP-005, Safety } \\
\text { Analysis Report for Packaging } \\
\text { (Onsite) for the Modified Fuel Spacer } \\
\text { Burial Box, Westinghouse Hanford } \\
\text { Company, Richland, Washington. }\end{array}$ \\
\hline JMTR Cask & 2 at $T$ Plant & 13.8 & $\begin{array}{l}9.5 \mathrm{in} . \\
\text { lead }\end{array}$ & optional & $\begin{array}{l}\text { Basket: } \$ 75,000 \\
\text { SARP: } \$ 50,000 \text { (Depends on } \\
\text { use) }\end{array}$ & \\
\hline
\end{tabular}




\begin{tabular}{|c|c|c|c|c|c|c|}
\hline RSI 1500 & $\begin{array}{l}9 \text { available for } \\
\text { purchase from } \\
\text { STERIGENIC } \\
\mathrm{s}\end{array}$ & $\begin{array}{l}0.55 \\
6\end{array}$ & $11 \mathrm{in.} \mathrm{lead}$ & optional & $\begin{array}{l}\text { Procurement: } \$ 20,000 \text { each } \\
\text { SARP: } \$ 75,000\end{array}$ & $\begin{array}{l}\text { NRC, 1992, Certificate of Compliance } \\
\text { for Radioactive Materials Package the } \\
\text { model 1500, USA/5939/B( )F, U.S. } \\
\text { Nuclear Regulatory Commission, } \\
\text { Washington, D.C. }\end{array}$ \\
\hline BUSS Cask & 1 at Hanford & 5.43 & $\begin{array}{l}13 \mathrm{in.} \\
\text { steel }\end{array}$ & no & $\mathrm{n} / \mathrm{a}$ & $\begin{array}{l}\text { DOE, } 1995 \mathrm{~b}, \text { Certificate of } \\
\text { Compliance for Radioactive Materials } \\
\text { Package, Beneficial Uses Shipping } \\
\text { System, USA/9511/B( U), U.S. } \\
\text { Department of Energy, Washington, } \\
\text { D.C. }\end{array}$ \\
\hline GE-2000 & $\begin{array}{l}\text { Available for } \\
\text { lease from GE }\end{array}$ & 17.2 & 8 in. lead & no & $\begin{array}{l}\$ 50,000 / \text { mo lease } \\
\$ 20,000 \text { deposit } \\
\$ 20,000 \text { SARP }\end{array}$ & \\
\hline Type A boxes & Varies & 225 & none & optional & $\begin{array}{l}\$ 750 \text { to } \$ 5000 \text { (depending on } \\
\text { size) }\end{array}$ & $\begin{array}{l}\text { WHC-SD-TP-SARP-018, Safety } \\
\text { Analysis Report for Packaging } \\
\text { (Onsite) for Type B Quantities of } \\
\text { Radioactive Material in Type A Boxes, } \\
\text { Westinghouse Hanford Company, } \\
\text { Richland, Washington. }\end{array}$ \\
\hline Drums & Available & 7.35 & none & yes & $\$ 5,000$ & $\begin{array}{l}\text { WHC-SD-RE-SAP-024, Safety } \\
\text { Analysis Report for Packaging } \\
\text { (Onsite) Non-TRU, Non-Fissile } \\
\text { Radioactive Material in the 55-Gallon } \\
\text { Drum, Westinghouse Hanford } \\
\text { Company, Richland, Washington. } \\
\text { WHC-SD-RE-SAP-033, Transuranic } \\
\text { Radioactive Material in the 55-Gallon } \\
\text { Drum, Safety Analysis Report for } \\
\text { Packaging (Onsite), Westinghouse }\end{array}$ \\
\hline
\end{tabular}




\begin{tabular}{|l|l|l|l|l|l|l|}
\hline & & & & & & $\begin{array}{l}\text { Hanford Company, Richland, } \\
\text { Washington. }\end{array}$ \\
\hline $\begin{array}{l}\text { Lead-lined } \\
\text { Drum }\end{array}$ & 14 at Hanford & 1 & 6 in. lead & yes & $\$ 11,000$ & $\begin{array}{l}\text { WHC-SD-WM-SARP-001, Safety } \\
\text { Analysis Report for Packaging } \\
\text { (Onsite) Lead Lined Drum/21-PF-1 } \\
\text { Packaging System, Westinghouse } \\
\text { Hanford Company, Richland, } \\
\text { Washington. }\end{array}$ \\
\hline $\begin{array}{l}\text { Concrete- } \\
\text { shielded Drum }\end{array}$ & 10 at Hanford & 0.69 & $\begin{array}{l}6.7 \text { in. } \\
\text { concrete }\end{array}$ & yes & $\$ 6,000$ & $\begin{array}{l}\text { WHC-SD-TP-SEP-051, Safety } \\
\text { Evaluation for Packaging (Onsite }) \\
\text { for the Concrete-Shielded RH TRU } \\
\text { Drum for the 327 Postirradiation } \\
\text { Testing Laboratory, Westinghouse } \\
\text { Hanford Company, Richland, } \\
\text { Washington. }\end{array}$ \\
\hline
\end{tabular}


For TSD facilities operating under Interim Status, the waste codes and waste management methods are described in the Part A Permit Application. Changes proposed to the dangerous waste inventory or the waste management methods for Interim Status facilities must be approved in a revision to the Part A Permit Application. The process for revising the Part A Permit Application, as specified in WAC 173-303-281, requires that a Notice of Intent be submitted. The public comment period for the Notice of Intent is 90 days; the entire approval process for a permit revision typically takes 9 to 12 months.

If the radioactive air emissions from a Hanford Site building are subject to change because of a proposed increase in the radioactive material inventory or revised waste-handling or emission-control methods, a Notice of Construction (NOC) must be submitted to the Washington State Department of Health (WDOH) and the EPA for approval. These requirements are specified in 40 CFR 61.07, "Application for Approval of Construction/Modification to an Existing Radioactive Air Emissions Source" and WAC 246-247-060, "Approval to Construct/Modify an Air Emissions Unit." The NOC approval process typically takes two to three months if the WDOH does not require significant revisions and resubmittal of the NOC.

DOE/RL-95-07, Hanford Site Air Operating Permit Application, (DOE-RL 1995) identifies the sources of radioactive air emissions on Hanford Site. The permit application is revised quarterly to incorporate special provisions identified in newly approved NOC. Modifications proposed under an NOC may commence once the NOC is approved.

Radioactive emissions from the CWC are not expected to change as waste is received, provided that the waste is packaged in accordance with WHC-EP-0063-4, Hanford Site Solid Waste Acceptance Criteria, (Willis 1993). A NOC would not be required to ship SCW to the CWC or the low-level burial grounds. Adding radioactive waste to the Hanford Site canyons may result in the potential for increased radioactive air emissions because of the increase in radioactive inventory, the addition of radionuclides not previously considered, or new wastehandling or waste-management activities that would be required. Transferring SCW to the PUREX tunnels or to T Plant would, therefore, require submittal and approval of a NOC.

\subsection{Quality Assurance Requirements}

Packaging, transportation, and storage activities, including the design, procurement, fabrication, installation, modification, inspection, and test of equipment and systems to accomplish the required physical facility upgrades, shall comply with the applicable PHMC Quality Assurance Program requirements.

\subsubsection{Packaging and Transportation}

The QA Program requirements applicable to packaging and transportation are specified in the associated SARP and SEP. These requirements shall be implemented through Project Hanford Procedures HNF-PRO-154, Responsibilities and Procedures for all Hazardous Material and HNF-PRO-157, Radioactive Material/Waste Shipments. 
HNF-2570, Rev. 0

\subsubsection{Storage and Physical Facility Upgrades}

The QA Program requirements applicable to storage and physical facility upgrades shall be specified by the organization operating the storage facility in accordance with the requirements of the applicable permits, facility Safety Analysis Reports, Quality Assurance Program Plans, and Project Hanford Procedures. 
HNF-2570, Rev. 0

This page intentionally left blank. 


\subsection{ALTERNATIVE GENERATION}

This chapter covers the identification of alternatives, decision criteria, and screening process used to develop the set of potentially viable alternatives. In addition, an initial screening is documented (see Section 4.3) on the alternatives identified in Section 4.1. Section 4.4 includes a detailed description of the alternatives that passed the initial screening and includes administrative and physical upgrades that would be required to implement the alternative.

\subsection{Identification Process}

This section describes alternatives considered for interim storage and disposition of the 324 and 327 Buildings SCW. This study updates the PNNL study (PNNL 1995) that examined options available at that time for removing certain remote-handled MW from the 324 Building. The alternatives will include, but will not be limited to, those examined in the PNNL study.

Alternatives involving research and development activities (such as treatment concepts) and possible offsite options were dismissed as not viable because of their inability to meet schedule needs and the associated uncertainties. The study focused on onsite interim storage alternatives that will not preclude any future treatment before final disposal. Consequently, removing the waste from interim storage, treating and/or repackaging, and shipping it to a permanent disposal repository will be required, but future actions are beyond the scope of this study.

Potentially viable alternatives to be considered include the following:

- PUREX tunnels

- Canyon facility*

- $\quad$ CWC building/storage pad/burial grounds (SWBG)**

- New facility

- Canister storage building (CSB).

* Canyon Building: An approximately 1000 feet long concrete structure with heavy walls serving as radiation shields for remote internal radiochemical processing (e.g., T Plant, PUREX, etc.).

**Burial Grounds: A specified excavated area suitable for sub-surface disposal of approved, packaged, radionuclide waste.

These alternatives were derived through a final alternative identification process conducted by recognized subject-matter experts from the Hanford Site based on their experience with similar waste disposition issues and/or their familiarity with the facilities being considered to accept the SCW (Parsons 1997).

Several facilities could be used for long term storage of radionuclide material. These are: $\mathrm{S}$-canyon, U-canyon, B-canyon, T-canyon and A-canyon (PUREX). They are in various stages of operation or shutdown. Because of operational status some or most may be excluded from 
long term storage of waste material at this time. After careful technical review, some or all of these facilities may be considered for repositories at a later date. This study considered only the T Plant case because of its operational status.

\subsection{Decision Criteria}

The decision criteria from HNF-IP-1289, Rev. 1, 324/327 Buildings Stabilization/Deactivation Project Project Management Plan, Section 5 were used in assessing the identified alternatives. The decision criteria were used to screen the alternatives (go/no go) using the process described in Section 4.3 and may be used to break ties between alternatives with similar costs and schedules. These criteria were developed as performance measures that can be used to evaluate alternatives supporting issue resolution and decision-making processes as part of HNF-IP-1289, Rev. 1. The performance measures represent a mixture of quantitative and qualitative factors; however, the quantitative evaluation was only conducted for those alternatives that passed the initial screen (see Sections 4.5 though 4.8). The following criteria were used to evaluate the alternatives during the initial screening.

Safety. Alternatives will be assessed on the basis of associated hazards and their implications for onsite and offsite safety, worker safety, and property protection. This evaluation will include a brief summary of the known hazards, mitigating circumstances, and existing safety analysis.

Environmental. The environmental (regulatory) impacts of the alternatives will be assessed by evaluating the following factors: air quality considerations, DW and permitting requirements, and stakeholder acceptance.

Complexity of Interfaces. The complexity of interfaces between the alternative and other systems and services is assessed by evaluating compatibility with existing systems and complexity introduced by needed changes, requirements for support functions and facilities, and the number and diversity of organizations that must be involved in implementation.

Risk. The risk associated with a particular alternative can be examined by identifying uncertainty associated with the alternatives and the potential impact to alternative selection or implementation.

Cost/Schedule. The equipment, system, or component will be evaluated with respect to rough-order-of-magnitude capital, operating (including waste handling, analytical, and preparatory paperwork), and life-cycle costs. Implementing schedules and associated schedule risk will be assessed relative to implementation of a given alternative. Tri-Party Agreement and other internal (BWHC) or external (DOE, regulatory, stakeholder) schedule requirements will be considered.

Operability/Maintainability. This criterion is used for equipment and systems installed for long-term surveillance and maintenance (S\&M) (i.e., exhaust fans, monitors, surveillance). 
Evaluating the complexity, reliability; and reparability of equipment and components can determine the maintainability of a system and its associated equipment and components.

\subsection{Initial Alternative Screening}

This section relates the results of the qualitative screening for the identified alternatives based on the go/no-go decision criteria.

\subsubsection{PUREX Tunnels}

The tunnels currently store waste similar to the SCW and have significant shielding and containment to prevent worker and public exposure (after the waste is in place).

Safety. Adding the remaining SCW waste to the current inventory in the tunnel will require an unreviewed safety question determination and supporting Hazards Analysis. The current authorization basis for the PUREX Tunnels is the PUREX Plant Final Safety Analysis Report (FSAR). The USQ and hazard analysis will be required to determine that the addition of material will not exceed the accident consequences currently identified in the FSAR.

Environmental. The facility currently operates under a Part B RCRA permit for the storage of MW. Added inventory would require a modification to the Permit appendices. An NOC would have to be approved to authorize changes to the air emission estimates resulting from the addition of the SCW. Tunnel stack monitoring will be upgraded to meet WDOH requirements. In an October 28, 1997, meeting with the WDOH and previous meetings with Ecology, no significant environmental or regulator acceptance issues were identified. In addition, recent discussions with the WDOH have indicated that the stack monitoring upgrades will be sufficient. Final stack upgrades and curie loading will be discussed in the Notice of Construction prior to the re-opening of the tunnels to obtain final WDOH approval.

Complexity of Interfaces. The tunnel is an independent structure. The alternative would require the addition of electrical service for material placement (lighting, crane, ventilation, outer door, shield door, and air emission monitoring). Additional interfaces (besides the generating facilities) include packaging and transportation engineering; crane and rigging services; rail services; and interfaces with regulators and Waste Management Federal Services of Hanford, Inc. (WMH). Because rail services are being discontinued in July 1998, there will be interface issues in obtaining tracks, brakes, cars, maintenance, and inspection services and operations support needed to release brakes or disable complex. However, no insurmountable interface issues have been identified.

Risk. The alternative requires the use of several assumptions that contain some degree of uncertainty. First, although significant opposition from regulators or stakeholders has not been encountered, this decision will require DOE and regulator acceptance. Second, the tunnels were deactivated in a manner that allows them to be reopened if additional storage was required, however several physical considerations must be addressed: 
- The transfer of unshielded waste in the tunnels will require installation of a crane and closed-circuit television inside the tunnel for remote transload capabilities

- The rail track and engine ('lil toot) will require at least minimal maintenance and some track replacement may be necessary

- The tunnels will have to be reopened after having been closed for over a year. Contamination levels and door operability are assumed to present minimal problems. Electrical service, which currently is disconnected, will be required to the outside tunnel door, some inside lights, and the Number 2 tunnel shield door. Although several technical and programmatic risks exist, no insurmountable issues or unreasonable assumptions exist.

Cost/Schedule. The cost of opening and closing the tunnels is assumed to be comparable to other alternatives that do not include new facilities. Long-term S\&M is insignificant based on current tunnel S\&M estimates and the cost of future retrieval of the SCW. Overall cost for retrieving tunnel waste for final disposal in the event of tunnel closure will not increase significantly. Tunnel availability should meet the requirements of the shipping schedule for waste from the 324 Building.

Operability/Implementability. PUREX is currently in a S\&M mode and is used to store mixed SCW.

Maintainability. The tunnels may require additional maintenance if adding the SCW changes the stack classification (National Emissions Standards for Hazardous Air Pollutants) from minor to major. This would require some maintenance on stack fans and monitoring systems.

Initial Screen Decision. This alternative has been selected in the past and the tunnels have not been significantly changed during PUREX deactivation to preclude future waste acceptance. The alternative will be reviewed further.

\subsubsection{Canyon Facilities (T Plant)}

Canyon facilities are integral parts of process buildings located in the Hanford Site 200 Areas. The canyons themselves are designed to provide heavy shielding during radioactive material handling and contain many cells under the canyon deck. The cells are further shielded with heavy removable cover blocks. Interim storage of waste in these canyon cells has been identified as a potential option. The Hanford Site contains several canyon facilities (U Plant, T Plant, PUREX, B Plant) that have the space and shielding required to safely store the 324 building SCW. Of these, only B Plant and T Plant have active systems (i.e., ventilation, cranes, electrical) that could support waste package receiving, handling, and storage. B Plant is currently being transitioned to a limited S\&M mode pending final decontamination and decommissioning (D\&D). Options for SCW storage are not included in the transition planning. Therefore, T Plant will be the only canyon facility considered as an interim waste storage option in this study. 
The T Plant canyon is a fully operational waste treatment and storage facility. Treatment and storage of dangerous waste at T Plant is described in Section 4.2.1.6 of the Hanford Facility Dangerous Waste Part A Permit Application (DOE-RL 1988). T Plant will continue to operate under 'interim status' under the Part A Permit Application until final closure. The Part A Permit allows T Plant to treat and store most hazardous waste constituents that have been identified on the Hanford Site, including those that have been identified in the SCW.

Safety - The T Plant canyon was analyzed for activities associated with storage, decontamination and recycle, and maintenance and refurbishment of contaminated equipment and preparation for disposal of equipment [refer to Section 2.3 of the Interim Safety Basis for Solid Waste Facilities, T Plant (Meyer, 1997)]. After fuel removal in 2002, T Plant is scheduled for deactivation, including shut-down of some of the active plant systems. The Memorandum of Understanding: Radionuclide and Hazardous Material Source Term for the T Plant Safety Documents (Appendix F in HNF-WM-ISB-006, Rev. 0, Interim Safety Basis for Solid Waste Facilities, $T$ Plant) (Meyer 1997) assumes a maximum inventory of 1,311 $\mathrm{Ci}$ of solid waste in containers outside the 221-T canyon, the activity levels specified in Table 1 for the Pressurized Water Reactor core, $1.63 \mathrm{MCi}$ in the canyon waste tank system, and a limited inventory from the sand filter and 291-T filter. No inventory of waste containers was assumed for storage in the canyon. Adding the 324 and 327 Buildings SCW to the T Plant canyon or cells would significantly change the source term used in the current safety analysis. Because the facility was not analyzed for storing high-activity waste and because of the significant change of the source term, storing SCW would require that a new safety analysis be completed and the facility's interim safety basis (ISB) be reevaluated and revised if necessary. Depending on the results of this analysis, plant upgrades also may be needed. In addition to the source term limits in the ISB, the fissile material limit for $221-\mathrm{T}$ is $900 \mathrm{~g}$. The current inventory of fissile material in the canyon is $137 \mathrm{~g}$.

Environmental. The T Plant interim status permit allows for storing a wide variety of MW. As discussed in Section 1.2, a Notice of Intent would be required to modify the T Plant section of DOE/RL-88-21, Hanford Site Dangerous Waste Part A Permit Application (DOE-RL 1988) to allow storage of SCW. In addition, National Environmental Policy Act of 1969 (NEPA) documentation, probably an environmental assessment (EA), would be required to expand the $T$ Plant mission to include the long-term storage of SCW. A NOC also would have to be submitted and approved by WDOH to authorize a modification to the radioactive air emission source term for T Plant.

Complexity of Interface. T Plant currently conducts $S \& M$ of the spent fuel pool temperature and chemistry because Shippingport reactor assemblies are being stored. If SCW were stored on or below deck, any transfer, placement, and storage of SCW would need to be conducted in such a manner (i.e., loading, shielding) to avoid hampering the ability to conduct routine operations for the spent fuel pool, including future removal operations. Additional interfaces include packaging and transportation engineering, rail services, and interfaces with the regulators and WMH. 
Risk. This alternative requires the use of several assumptions that contain some degree of uncertainty. A safety analysis must be performed to allow T Plant to accept SCW for longterm interim storage and update the interim status permits must be updated to include SCW. These actions could take up to 1 year and identify additional facility upgrades to be made before waste acceptance. In addition to the NEPA and permit revisions, an agreement in principle to allow long-term storage of SCW at T Plant would be required. DOE and regulator acceptance of. this change in mission and long-term planning is uncertain.

Operability/Implementability. After packaging, loading, and transporting, the waste would arrive at the T Plant rail tunnel on a flat car in the SWDB or other exterior container that the $\mathrm{T}$ Plant canyon crane can handle easily. In preparing for the waste receipt, $\mathrm{T}$ Plant operations would have prepared a canyon cell by removing and staging the cell cover blocks and clearing any equipment from the cell. Operations also would establish ability to retrieve the waste packages from the exterior container and transfer them directly from the tunnel into the prepared canyon cell.

Alternatively, the exterior container might be hoisted into the canyon and placed on the canyon deck (if its physical size allows) where it could be prepared for opening. Personnel would then be evacuated and the waste packages transferred by remote operation to the cell. Cover blocks are replaced as the last step. If the waste is to be left in shielded containers, these could be stored on the canyon deck (a canyon deck/cover block load evaluation would be required). This strategy would be restricted by a $40,824 \mathrm{~kg}$ (45-ton) weight limit. The overhead

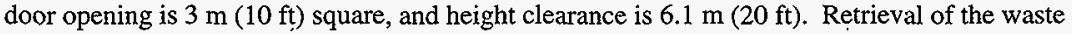
for transfer to a final disposal site is expected to involve a similar effort, reversing the steps.

Waste containers would be stored in a canyon cell to take advantage of the additional shielding it provides. Several cells reportedly are empty and would be available; however, verification and inspection of cell integrity should be a prerequisite to waste placement.

Maintainability. Current maintenance of the canyon cranes and electrical and ventilation systems would be required until the shipping port Pressurized Water Reactor fuel is removed, which is currently planned to be completed by 2002 . These annual costs would be required for as long as $\mathrm{SCW}$ is stored in the canyon.

Initial Screen Decision. All previous studies have eliminated this alternative because of its safety bases and permit limitations. Unknown upgrade costs (administrative and physical) and safety basis and permitting revisions required make the $T$ Plant alternative less desirable than the PUREX tunnels and CWC. Therefore, this study will not consider this alternative further. 


\subsubsection{Central Waste Complex Building/Storage Pad/Burial Grounds}

The CWC and the Solid (or Low Level) Waste Burial Ground (SWBG) are two TSD components of the Hanford site permit system. They currently operate under an interim status through a Part A permit application. The CWC accepts LLW, LLMW, TRU, and mixed TRU wastes subject to package limits, surface, and $30 \mathrm{~cm}$ dose rates. SNF or high-level waste are not permitted. The SWBG currently has a limited amount of TRU in EBR-II casks with future limits on added TRU. Normally this facility accepts LLW and remote-handled LLW for burial. Most of the wastes listed in the special-case waste lists do not fall within those categories. A finalstatus permit application is scheduled for incorporation in 1998. The CWC accepts only contacthandled waste and remote-handled waste shielded to contact-handled levels.

Safety. The CWC and burial grounds are currently used for the long-term storage of a wide variety of MW. The addition of 324 Building waste, if it meets the waste acceptance criteria, would have no adverse safety impact on the CWC.

Environmental. The CWC and burial grounds are interim-status facilities addressed in the Hanford Site Part A Permit for the long-term storage and disposal of MW. Shipment of the 324 and 327 buildings waste to existing facilities would not require any changes or updates to the existing RCRA permit. However, if additional storage space were needed (i.e., a new storage pad), NEPA documentation, probably an EA, would have to be prepared. In addition, a NOC would have to be submitted and approved by WDOH to authorize a modification to the radioactive air emission source term for the CWC.

Complexity of Interface. Additional interfaces (besides the generating facility) include packaging and transportation engineering, rail services, and interfaces with the regulators and WMH.

Risk. This alternative requires the use of several assumptions that contain some degree of uncertainty, including whether CWC will accept the proposed storage containers. In addition, getting approval for and constructing a new pad could be time consuming. However, no insurmountable issues or unreasonable assumptions are presently known.

Operability/Implementability. Normal waste is routinely shipped and received by the CWC and no operability or implementability issues are foreseen.

Maintainability. Some waste types may require periodic venting depending on the type of venting mechanisms involved. In addition, routine surveillance and inspection of the waste containers will be required.

Initial Screen Decision. This alternative is viable and should be evaluated further. 


\subsubsection{New Facility}

A new remote-handled waste storage facility for SCW containment was previously evaluated. Such a facility was estimated to take three years to construct and cost over $\$ 10 \mathrm{M}$ (DOE 1985). This alternative will not be considered further for two reasons. First, it apparently is unable to meet cost and schedule criteria. Second, it would build a new facility that subsequently would require deactivation and $\mathrm{D} \& \mathrm{D}$. This conclusion also was reached in PNL-10623 (PNNL 1995) report, and indications are that these constraints will be no less severe now than at that time.

\subsubsection{Canister Storage Building}

The CSB was originally designed to receive and store vitrified waste. Specifications called for building three storage vaults each with 400 storage tubes $61 \mathrm{~cm}$ (24 in.) in diameter and $406 \mathrm{~cm}$ (160 in.) long. With uncertainty about the future of a vitrification plant and the immediate need for addressing the K-Basin fuel issue, the CSB mission has been redirected toward accepting the K-Basin fuel inventories. In addition, budget constraints have narrowed the CSB construction plans to completion of only one of the three storage vaults (scheduled for June of 1998), with the other two vaults remaining as open pits.

The CSB is not considered viable because of its permitting limitations and limited capacity. The CSB design only allows for storage of SNF. Some of the waste material outside the scope of this study includes SNF in B-Cell and D-Cell. The disposition of this material has been defined. Virtually all vault storage at the CSB is committed to the K-Basin fuel inventories.

\subsection{Selected Alternatives}

The remaining alternatives, which are to be considered further, are the PUREX Tunnels (both the shielded and unshielded options) and the CWC Storage/Burial Grounds. Both of the identified waste streams (B-Cell dispersibles and HLV residuals) have no known restrictions prohibiting their placement in either of these alternatives.

\subsection{PUREX Tunnels}

\subsubsection{Alternative Description}

The PUREX tunnel system is an option considered for storing the SCW. The system consists of the railroad tunnel and Tunnels 1 and 2. The railroad tunnel is perpendicular and runs under the East End of the PUREX canyon. It was used as access for transferring equipment and material in and out of the canyon. The railroad tunnel is below the cell cover block level of the canyon and was entered by using the canyon crane to hoist equipment through the horizontal rollaway overhead door (ventilation barrier). The railroad tunnel extends south of the canyon facility through water-fillable shield doors into the storage tunnels. 
HNF-2570, Rev. 0

Only Tunnel 2 will be considered to store the SCW. Tunnel 2 will be ventilated by a system located at the south end of the tunnel. The system consists of a fan with a volume of approximately $142 \mathrm{~m}^{3} / \mathrm{min}\left(5,000 \mathrm{ft}^{3} / \mathrm{min}\right)$ and stack and monitoring equipment. The system is currently blanked and will require maintenance, an upgrade of the sampling equipment, and power service. For this analysis, the ventilation system is considered to have sufficient capacity to prevent outside airborne contamination spread at the opening of the railroad tunnel. The stack sampling equipment presently in place does not meet the National Emissions Standards for Hazardous Air Pollutants requirements and will be upgraded in accordance with Ecology. A recommendation is being prepared for review and acceptance by the WDOH to open the tunnels following the upgrade to the sampling equipment.

A portion of the original inventory of B-Cell dispersible debris was placed in Tunnel 2 in July 1996. Since that time the PUREX canyon facility has been placed in long-term S\&M mode, pending. The overhead door in the railroad tunnel has been sealed off, the canyon ventilation has been substantially reduced, and the crane electrical power has been disconnected. The resultant physical status of the PUREX canyon and the operational limitations stated in the PUREX BIO, preclude using the canyon or any associated equipment (crane) for any waste-handling operations inside the railroad tunnel.

The following two options are considered for placing the SCW into PUREX Tunnel 2.

Option 1 (PUREX Unshielded). This option involves bringing the waste into the railroad tunnel in an SWDB (commonly referred to as a 22-1/2-ton box), then removing the unshielded inner liner containing the waste from the SWDB and placing it on a flat car. The flat car then would be pushed into Tunnel 2. This option would require the installation of a crane in the railroad tunnel to facilitate handling. Because of the high radiation levels of the waste, the crane would be remotely controlled.

Option 2 (PUREX Shielded). This option involves loading the entire SWDB onto a flat car outside the railroad tunnel, then pushing the flat car in to Tunnel 2. This option would require the temporary use of a portable crane to transfer the shielded containers from the vehicle that brought the waste from the 300 Area to the flat cars that would be pushed into the tunnel. The waste would be stored in the shielded shipping containers inside the tunnel.

Hydrogen generation rates and the resultant concentrations inside the tunnel have been analyzed. The potential hydrogen buildup does not pose a safety threat (SAIC 1995).

\subsubsection{Safety Basis}

Option 1 (PUREX Unshielded). Safety concerns are associated with operating the new crane that would be installed in the railroad tunnel and the additional waste inventory. The following activities are needed to address these concerns.

1. Develop an unreviewed safety question (USQ) evaluation for the crane operation. 
HNF-2570, Rev. 0

2. Perform a hazard analysis of the crane operations.

3. Perform a safety analysis evaluating the high-hazard operations.

4. Develop a USQ evaluation for the material storage in the tunnels. The evaluation will determine the accident scenario consequences associated with the additional material and determine if they are acceptable under the current authorization basis.

5. Evaluate the material to ensure that it complies with the current criticality prevention specifications.

6. Perform a readiness assessment and review.

Option 2 (PUREX Shielded). For the shielded option, only activity Item 4 under Option 1 would need to be performed. The USQ determinations would have to consider only the change in the radioactive waste inventory because no new hazards are being introduced by analyzed waste-handling operations.

\subsubsection{Permit Condition}

The following conditions apply to both options. The tunnels currently operate under a RCRA permit, which must be revised. A NOC is required. The NOC becomes a form of a permit and is a mechanism to modify the Air Permit. A NEPA review also would be performed.

\subsubsection{Physical Upgrades Needed}

Option 1 (PUREX Unshielded). The following upgrades would be required for Option 1. The normal process of installing equipment in the railroad tunnel is complicated by all work being performed in a zone containing low-level surface contamination.

1. Install a crane in the railroad tunnel for loading (includes adding crane rails to the tunnel floor).

2. Install closed-circuit television equipment to operate crane remotely.

3. Install additional lighting in the railroad tunnel.

4. Provide permanent power to the crane and temporary power to the vertical and water-fillable doors.

5. Repair damaged track at the entrance to Tunnel 2 .

6. Upgrade stack monitoring equipment at the south end of Tunnel 2. 
7. Inspect ventilation equipment and upgrade components as needed.

Option 2 (PUREX Shielded). The following upgrades would be required for Option 2. The normal process of installing equipment in the railroad tunnel is complicated by all work being performed in a zone containing low-level surface contamination.

1. Provide temporary power to railroad tunnel vertical and water-fillable doors.

2. Install additional lighting in railroad tunnel and provide temporary power.

3. Repair damaged track at the entrance to Tunnel 2.

4. Upgrade stack sampling equipment at south end of Tunnel 2.

5. Inspect ventilation equipment and upgrade components as needed.

\subsubsection{Fixed Costs and Schedule}

Table 4-1 summarizes the fixed costs and schedule for both options.

\begin{tabular}{|l|r|r|}
\hline \multicolumn{3}{|c|}{ Table 4-1. Summary of Fixed Cost and Schedule for PUREX Tunnel Options. } \\
\hline \multicolumn{1}{|c|}{ Facility Requirements } & $\begin{array}{r}\text { Option 1 } \\
\text { PUREX Unshielded }\end{array}$ & $\begin{array}{c}\text { Option 2 } \\
\text { PUREX Shielded }\end{array}$ \\
\hline Safety documentation & $\$ 140,000$ & $\$ 39,232$ \\
\hline Permit documentation & $\$ 130,000$ & $\$ 25,727$ \\
\hline Stack Sampling Tests & $\$ 56,820$ & $\$ 56,820$ \\
\hline \multicolumn{3}{|c|}{ Facility Upgrades } \\
\hline Ventilation & $\$ 124,036$ & $\$ 124,036$ \\
\hline Material handling/power/access & $\$ 1,045,000$ & $\$ 554,988$ \\
\hline Program management & $\$ 136,620$ & $\$ 136,620$ \\
\hline Total fixed costs & $\$ 1,632,476$ & $\$ 937,423$ \\
\hline \multicolumn{3}{|c|}{ Jan 2000 } \\
\hline Ready to receive waste & Jan 2000 \\
\hline
\end{tabular}


HNF-2570, Rev. 0

\subsection{CWC Building/Storage Pad}

Because much of the waste removed from the 324 and 327 Buildings will be classified as TRU, mixed TRU), GTC3 LLW, or GTCC LLW, the waste will not be allowed to be disposed of in near-surface burial grounds. These waste streams will require storage. One option, as described here, is to store the waste at the CWC.

\subsubsection{Alternative Description}

The CWC is available for storing TRU, mixed TRU, and GTCC waste, provided the waste packaging meets the CWC acceptance criteria. Consideration of this alternative assumes that a dedicated storage pad similar to the one used for the FRG logs will be fabricated. This assumption probably is valid because of the large mass of the storage casks. The cost estimate included includes the fabrication of the storage pad.

\subsubsection{Safety Basis}

The CWC has a safety analysis that supports existing operation. A USQ screening and evaluation will be required for the new waste storage pad, as was required for the FRG logs. A safety assessment may be required in accordance with the facility authorization basis. An engineering change notice (ECN) to the safety basis documentation also may be required.

Limits on total radionuclide content for waste stored at the CWC are specified in HNF-SD-WM-ISB-007, Central Waste Complex Interim Safety Basis, (Bendixsen 1997). These limits on radionuclide content for storage at the $\mathrm{CWC}$ are based on dose-equivalent-curies (DE-Ci) of ${ }^{239} \mathrm{Pu}$. The calculation method for determining $\mathrm{DE}-\mathrm{Ci}$ for a given radionuclide activity distribution in a waste package is described in Appendix $\mathrm{E}$ of the CWC ISB and in WHC-EP-0063, Hanford Site Solid Waste Acceptance Criteria, (Willis 1993). The DE-Ci values are calculated by multiplying the curie amount for each radioisotope by a corresponding DE-Ci conversion factor. The sum of the $\mathrm{DE}-\mathrm{Ci}$ values for all radioisotopes in a waste package is the $\mathrm{DE}-\mathrm{Ci}$ value for that package.

The accident analysis for the CWC assumes $53 \mathrm{DE}-\mathrm{Ci}$ per package. A lower operating limit of $35 \mathrm{DE}-\mathrm{Ci}$ per package has been established to be conservative. Packages exceeding $35 \mathrm{DE}-\mathrm{Ci}$ are administratively controlled so that the average $\mathrm{DE}-\mathrm{Ci}$ loading in the building areas does not exceed the safety analysis assumptions. Packages with less than 35 DE-Ci have no restrictions for storage at the CWC if all other criteria listed in WHC-EP-0063, the Hanford Site Solid Waste Acceptance Criteria (Willis 1993) are met. The single package limit for storage at the CWC is $150 \mathrm{DE}-\mathrm{Ci}$. The CWC building limit for packages containing more than $35 \mathrm{DE}-\mathrm{Ci}$ is $600 \mathrm{DE}-\mathrm{Ci}$. Type $\mathrm{B}$ containers do not have to meet the $\mathrm{CWC} \mathrm{DE-Ci}$ restrictions.

The CWC criticality limits are $200 \mathrm{~g}$ of fissile material for 55-gal drums, if dispersed over 20 percent of the container volume. If the fissile materials are not distributed over 20 percent of 
the container volume, the limit is $100 \mathrm{~g}$. The limit for lead-lined 55 -gal drums is also $100 \mathrm{~g}$ of fissile material. The limit for SWDB is $325 \mathrm{~g}$ of fissile material.

In this alternative, waste would be packaged into unshielded containers, then loaded into Type B or equivalent casks that provide design basis accident containment and substantial shielding. (In theory, very-high-dose rate, remote-handled MW may be stored in the CWC assuming sufficient shielding is used to reduce the radiation dose rates to the contact-handled limits). The casks would be loaded onto trucks and transported to the existing or specially designed storage area in the CWC. The waste casks would be unloaded by crane and stored in the complex.

The use of Type B or equivalent casks to overpack the waste is the distinguishing requirement associated with this alternative. Type $\mathrm{B}$ packaging is needed because the $\mathrm{DE}-\mathrm{Ci}$ limits on the CWC would require many more Type A packages than would be economically feasible. Type B packages are not restricted by DE-Ci loading.

\subsubsection{Permit Conditions}

The CWC and the SWBG are two TSD components of the Hanford Site permit system. They currently operate under interim status through a Part A permit application. The CWC facility accepts LLW, LLMW, TRU, and mixed TRU wastes subject to package limits and surface $\& 30 \mathrm{~cm}$ dose rates. SNF or high-level waste are not permitted. The SWBG currently has a limited amount of TRU in EBR-II casks with future limits on added TRU. Normally this facility accepts LLW and remote-handled LLW for burial. Most of the wastes listed in the Special-Case lists do not fall within those categories. After treatment (if required) and packaging, waste packages would be loaded into casks, which in turn would be loaded onto trucks and transported to the designated storage area in the SWBG. The waste and casks are then unloaded and left at the burial grounds or CWC for disposal intact. In general, waste that meets the criteria defined by WHC-EP-0063, the Hanford Site Solid Waste Acceptance Criteria (Willis 1993 ) is accepted. Waivers to the criteria can be applied for and cases are evaluated individually.

A NEPA review and documentation, most likely an EA will be required to construct a new waste storage pad. A finding of no significant impact would be required to avoid the need for an Environmental Impact Statement. No change to the existing Part A Permit application should be required.

\subsubsection{Physical Upgrades}

No physical upgrades will be required for this option.

\subsubsection{Fixed Costs/Schedule}

Acceptance of waste at the CWC is contingent on the waste generator paying a one-time fee. The fee is based on the type of waste (e.g., Greater-Than-Category-1 mixed, Category-3 
HNF-2570, Rev. 0

LLW, etc.) and waste package external dimensions. Once the one-time fee is paid, annual S\&M costs are absorbed by the CWC and are minimal per package.

Table 4-2 lists the fixed costs associated with this option. These costs are based on the fabrication of the FRG log storage pad.

\begin{tabular}{|l|r|}
\hline \multicolumn{2}{|c|}{$\begin{array}{c}\text { Table 4-2. Summary of Fixed Costs and Schedule for CWC } \\
\text { Alternative. }\end{array}$} \\
\hline \multicolumn{1}{|c|}{ Facility } & \multicolumn{1}{c|}{ Cost (\$) } \\
\hline Project management & 270,000 \\
\hline Environmental assessment & 45,000 \\
\hline Storage site design & 140,000 \\
\hline Storage site construction & 320,000 \\
\hline Storage site turnover & 55,000 \\
\hline $\begin{array}{l}\text { Final Safety Analysis Report } \\
\text { ECN }\end{array}$ & 90,000 \\
\hline Storage site procedures & 30,000 \\
\hline Total & 950,000 \\
\hline \multicolumn{2}{|c|}{ Schedule } \\
\hline Schedule duration & 12 months \\
\hline Ready to receive waste & May 1999 \\
\hline
\end{tabular}


HNF-2570, Rev. 0

\subsection{ALTERNATIVE ANALYSIS}

This section will include the detailed, stepwise look at each waste stream and its associated costs and schedules, and then will include an overall assessment based on the alternatives.

\subsection{Evaluation By Waste Stream}

Sections 5.1.1 and 5.1.2 contain a detailed evaluation of each waste stream, looking at prepackaging, packaging, transportation, placement, and post-placement activities required for each possible alternative. Cost estimates for each waste stream are provided in Appendices B and $\mathrm{C}$.

\subsubsection{B-Cell Dispersible Debris}

This section provides detailed information about the physical processes to remove the dispersible debris from B-Cell for storage at the CWC or the PUREX Tunnel 2. This waste stream consists of $1.3 \mathrm{~m}^{3}\left(47 \mathrm{ft}^{3}\right)$ of dispersible debris from the floor, $0.4 \mathrm{~m}^{3}\left(15 \mathrm{ft}^{3}\right)$ of dispersible debris from the pipe trench (pipe trench sludge) and $0.5 \mathrm{~m}^{3}\left(19 \mathrm{ft}^{3}\right)$ of debris from the six tanks in Racks 1A, 1B, and 2A. As explained in Section 2.1.1, this waste stream will be classified as mixed TRU. The total volume of dispersible debris to be shipped is approximately $2.3 \mathrm{~m}^{3}\left(81 \mathrm{ft}^{3}\right)$. The total curie content for this dispersible debris waste stream is estimated to be $3.8 \mathrm{MCi}$.

The $0.5 \mathrm{~m}^{3}\left(19 \mathrm{ft}^{3}\right)$ of debris in the tank heels cannot be effectively removed from the internal surfaces of the tanks. Chemical cleanup would be difficult because the piping connections have not been confirmed as built and the process lines could not be properly tested for integrity. Mechanical scraping would not remove the entire waste heel residue, so the tanks would remain classified as MW and would have to be packaged and disposed of in a manner similar to the heel residues. Because of the difficulties in removing the heel residue and because the tanks may have to be sectioned and disposed of as MW even if the heel were removed, the best disposition option for the B-Cell tanks is to section them with the heel inside. The tank sections would then be packaged and disposed of as mixed TRU. The total volume of the tanks and associated equipment is estimated to be $10 \mathrm{~m}^{3}\left(350 \mathrm{ft}^{3}\right)$. It is assumed that 50 percent of this volume (i.e., the upper half of each tank) can be removed and disposed of as LLW. This leaves $5 \mathrm{~m}^{3}\left(175 \mathrm{ft}^{3}\right)$, much of which is void space. It is further assumed that by segmenting and packaging, a 50 percent volume reduction would result, leaving $2.5 \mathrm{~m}^{3}\left(87 \mathrm{ft}^{3}\right)$ of material to be packaged as SCW. This $2.5 \mathrm{~m}^{3}\left(87 \mathrm{ft}^{3}\right)$ of waste consists of the $0.5 \mathrm{~m}^{3}\left(19 \mathrm{ft}^{3}\right)$ of tank heel residue and process vessel metal parts.

If the waste stream is to be packaged for storage in the PUREX tunnel, the packaging of choice is the SWDB (22.5-ton box). This is the container used to transfer dispersible debris and other waste to the PUREX tunnels before closure in 1996 (PNL 1996a, 1996b). The curie count 
of the material shipped during these campaigns was $102,700 \mathrm{Ci}(\mathrm{Cs}-\mathrm{Sr})$ and $15,500 \mathrm{Ci}(\mathrm{Cs}-\mathrm{Sr})$, respectively.

\subsubsection{Prepackaging Activities.}

The activities that must be performed before packaging the dispersible debris from B-Cell are described in the following paragraphs for placing the waste in the PUREX Tunnel or storing it at the CWC.

PUREX Tunnels. The floor and pipe trench dispersible debris will be prepackaged in engineered containers, which have a payload of $0.07 \mathrm{~m}^{3}\left(2.6 \mathrm{ft}^{3}\right)$. Each SWDB will contain eight engineered containers. The floor and pipe trench dispersible debris $\left[1.8 \mathrm{~m}^{3}\left(62 \mathrm{ft}^{3}\right)\right]$ will be contained in 21 engineered containers. Three SWDB will be required. The engineered containers and SWDB must be purchased.

Removing the three processing racks from B-Cell will allow any dispersible debris under the racks to be collected and the six tanks containing residual process feed to be separated from the racks. This activity will require engineered planning, procedure development, and other prejob activities. The rack structure and piping will be cut, packaged, and removed for disposal. Each tank will be staged for later cutting and packaging.

The $2.5 \mathrm{~m}^{3}\left(87 \mathrm{ft}^{3}\right)$ of tank structures and heels will be sectioned and placed in liners that will be placed directly into the two GNS-12 casks. Each liner holds approximately $1.4 \mathrm{~m}^{3}$ (50 $\mathrm{ft}^{3}$ ) of waste, so two liners and and both existing GNS-12 casks are required.

For this option, 21 engineered containers, two box liners, and five SWDB are required to handle the $\mathrm{B}$-Cell dispersible debris.

CWC Storage. The B-Cell dispersible debris from the floor has been estimated in this report to be $1,479 \mathrm{KCi}$. This estimate was obtained by using the original activity level of 1,500 $\mathrm{KCi}$ assumed to exist in the B-Cell floor debris before the 1996 shipment and subtracting the curie content of the engineered containers shipped in $1996(21 \mathrm{KCi})$ under Manifests 96004 and 96006 (PNL 1996a, 1996b). The curie content of the 6 tanks left in the B-Cell rack is estimated to be $2,331 \mathrm{KCi}$ based on past inventory records kept on processing operations. The airlock trench sludge has been estimated to contain approximately $10 \mathrm{KCi}$ based on an estimated volume of $0.5 \mathrm{~m}^{3}\left(15 \mathrm{ft}^{3}\right)$ and a curie-per-cubic-meter (curie-per-cubic-foot) concentration similar to the B-Cell dispersible debris packaged in 1996. The total curie inventory of SCW to be disposed of in $\mathrm{B}$-Cell is, therefore, estimated to be $3,820 \mathrm{KCi}$ with no decay assumed.

The total dose equivalent curies for a waste package are obtained by converting the activity level for each radionuclide to a ${ }^{239} \mathrm{Pu}$ equivalent and summing the $\mathrm{DE}-\mathrm{Ci}$ values for each radionuclide.

Appendix E, Table E-1 of the CWC ISB (Bendixsen 1997) provides the DE-Ci conversion factors for each radionuclide. A calculation of the DE-Ci value for one of the 1996 
HNF-2570, Rev. 0

waste shipments of B-Cell dispersible debris collected from the floor shows that $271 \mathrm{DE}-\mathrm{Ci}$ and $205,432 \mathrm{Ci}$ were included in the package (see Table 5-1).

\begin{tabular}{|c|c|c|c|}
\hline Radionuclide & $\begin{array}{c}\text { Curies from Solid Waste } \\
\text { Storage and Disposal } \\
\text { Record }\end{array}$ & $\begin{array}{c}\text { Dose Conversion Factor } \\
\text { from Table E-1 of CWC ISB }\end{array}$ & $\mathrm{DE}-\mathrm{Ci}$ \\
\hline Sr-90 & 43,162 & $3.02 \times 10^{-3}$ & 130.35 \\
\hline Cs-137 & 59,553 & $7.44 \times 10^{-5}$ & 4.43 \\
\hline $\mathrm{Eu}-154$ & 2.05 & $6.66 \times 10^{-4}$ & 0.001 \\
\hline $\mathrm{Pu}-238$ & & & 0.02392 \\
\hline Pu-239 & & & 0.79200 \\
\hline $\mathrm{Pu}-240$ & & & 0.25200 \\
\hline Pu-241 & & & 0 \\
\hline $\mathrm{Pu}-242$ & & & 0 \\
\hline Am-241 & & & 0.13700 \\
\hline Y-90M & $<43,162$ & & 130.35 \\
\hline $\mathrm{Ba}-137 \mathrm{M}$ & 59,553 & & 4.43 \\
\hline Totals & & & 270.76 \\
\hline
\end{tabular}

Although this calculation included the contribution of the dried feed material from the radioactive-liquid-fed ceramic melter as well as the dispersibles collected from the B-Cell floor, the $\mathrm{DE}-\mathrm{Ci}$ ratio obtained should be representative for the remaining B-Cell SCW. An estimate for the $\mathrm{DE}-\mathrm{Ci}$ content of the remaining $\mathrm{B}-\mathrm{Cell} \mathrm{SCW}$ was determined as follows:

$$
\text { Total B-Cell DE-Ci }=3,820 \mathrm{KCi} \times \frac{271 \mathrm{DE}-\mathrm{Ci}}{205 \mathrm{KCi}}=5,050 \mathrm{DE}-\mathrm{Ci}
$$

A more conservative calculation was made based on PNL-10623, Selection and Evaluation of Alternatives for the Removal of Solid Remote-Handled Mixed Waste from the 324 Building (PNNL 1995), which estimated that 2,800 DE-Ci would be present in the assumed total of $1,500 \mathrm{KCi}$ of dispersible debris in B-Cell. Using the more recently calculated curie content of $3,820 \mathrm{Ci}$ (includes curie contribution from the six tanks in the B-Cell racks), the projection would be $7,131 \mathrm{DE}-\mathrm{Ci}$. 
HNF-2570, Rev. 0

\section{$3,820 \mathrm{KCi} \times \underline{2800 \mathrm{DE}-\mathrm{Ci}}=7,131 \mathrm{DE}-\mathrm{Ci}$ \\ $1,500 \mathrm{KCi}$}

Accounting for decay since 1986, approximately 75 percent of the DE-Ci would remain, yielding a value of 5,348 DE-Ci. The DE-Ci limit for storage of any Type $\mathrm{A}$ container at $\mathrm{CWC}$ is $150 \mathrm{DE}-\mathrm{Ci}$ per container. Administrative controls are used to maintain the required total building DE-Ci by arranging all containers containing more than $32 \mathrm{DE}-\mathrm{Ci}$ in an approved configuration. Therefore, to store $5,348 \mathrm{DE}-\mathrm{Ci}$ at $\mathrm{CWC}$ would require a at least 36 Type $\mathrm{A}$ containers.

The prepackaging activities required for both options will be identical except for the packaging procurement activity. The packages required for CWC storage must be Type $B$ packaging or the dispersible debris packaged such that the waste form is exempt from inclusion in the CWC DE-Ci limit as part of the source strength control requirements found in HNF-SDWM-TSR-005, CWC Interim Operational Safety Requirements (Bendixen 1997). The packaging configurations identified for this waste disposition alternative are listed in Table 5-2.

\begin{tabular}{|l|c|l|}
\hline \multicolumn{3}{|c|}{ Table 5-2. Packaging Approach for Storage of the B-Cell } \\
Dispersibles at CWC. \\
\hline \multicolumn{1}{|c|}{ Package } & Volume/Package & Availability \\
\hline 2 GNS-12 Casks & $0.4 \mathrm{~m}^{3}\left(13.6 \mathrm{ft}^{3}\right)$ per cask & On hand \\
\hline 2 JMTR Casks & $0.3 \mathrm{~m}^{3}\left(9.6 \mathrm{ft}^{3}\right)$ per cask & On hand \\
\hline 5 CASTOR Casks & $\left(0.6 \mathrm{~m}^{3}\left(21.6 \mathrm{ft}^{3}\right)\right.$ per cask & Procure \\
\hline
\end{tabular}

This disposition option will require procurement of five CASTOR casks, safety analysis documentation, and liners for each cask. The fabrication and procurement of a dedicated storage pad may also be required.

\subsubsection{Packaging Activities}

PUREX Tunnel. The dispersible debris from the floor will be packaged in engineered containers using the same method as was used in the past:

1. Attach a heavy block to the crane and drag it across the floor to collect the debris.

2. Separate the larger waste items from the debris.

3. Use the B-Cell crane and the straight-edged clamshell to collect the dispersible solids and package them in engineered containers. 
HNF-2570, Rev. 0

4. Use other methods, such as a HEPA filtered vacuum, to collect the fines left after the block-dragging technique if necessary.

5. Check liner integrity. Seal defects.

6. Flush with water and use chemical decontamination to remove any remaining contaminants.

The sludge removal effort in the hot pipe trench must be coordinated with the B-Cell cleanout. The airlock pipe trench is covered with cover blocks that will require cleaning prior to staging in a clean section of the airlock or B-Cell after the blocks are cleaned. The technology required to collect the sludge from the trench will be dependent on the physical characteristics of the material in the trench. The sludge could be easily removed using a scraper or clamshell for transfer to engineered containers and subsequent use of sluicing with pump out to B-Cell. Final nuclide separation will occur in the D-Cell equipment.

As the engineered containers become filled, they will be packaged into the SWDB, which will hold eight engineered containers. The loaded box will be closed and shipped from the hot cell.

The sectioning and packaging of the B-Cell tanks and the tank heels will proceed by first placing the waste in liners, which will be placed in SWDB when full.

The current SARP for the SWDB (22 $\frac{1}{2}$-ton box) has a shipment limit of $100,000 \mathrm{Ci}$ of ${ }^{137} \mathrm{Cs}$ and $58,000 \mathrm{Ci}$ of ${ }^{90} \mathrm{Sr}$. Revisions will be required to allow the larger curie quantities that will be encountered in the B-Cell process vessel debris.

CWC Storage. The activities related to collecting the waste, vacuuming the fines, and removing any bound residuals attached to the cell surfaces are the same as for the waste packaged for the PUREX tunnel. Instead of being packaged in engineered containers and box liners, the waste will be packaged in special stainless steel liners. To provide containment, the liners may need to be seal welded or placed in a second vessel that is seal welded in either the air lock or Shielded Materials Facility. Rather than packaging the liners in the SWDB, they will be placed in either the GNS-12, the JMTR, or the CASTOR cask.

\subsubsection{Transportation Activities.}

PUREX Tunnel. Five SWDB will be transported to the PUREX Facility by truck. One SWDB will be loaded onto each truck.

CWC. Nine casks will need to be transported to the CWC. Only one cask can be shipped on a truck. Each shipment will require that the roads be closed and swept before transport. 
HNF-2570, Rev. 0

\subsubsection{Placement Activities}

PUREX Tunnel. In the shielded option, the SWDB will be loaded on trucks at the 324 Building, transported to the PUREX tunnel, transloaded to a flat car, and placed directly into PUREX Tunnel 2. In the unshielded option, the liners would be removed remotely and placed on a rail car for storage.

CWC. Each cask will be off-loaded from the transport trailer with a portable crane and placed directly to the final storage location, which would be a reinforced concrete pad.

\subsubsection{Post Placement Activities}

PUREX Tunnels. The SWDB will be placed directly into the PUREX tunnel following transport. No additional costs are assumed.

CWC. Surveillance and maintenance costs associated with storing the nine casks at the CWC will be consistent with other packages currently stored there. These containers will require venting. Additional costs for maintaining or replacing the venting filters should be minimal.

\subsubsection{Cost Summary}

Fixed costs to prepare the storage locations (PUREX Tunnels options and CWC) were provided in Section 4.5. The additional costs to prepare, package, transport, place and maintain the B-Cell dispersibles is estimated to be $\$ 857 \mathrm{~K}$ for the PUREX tunnel unshielded option, $\$ 1,314 \mathrm{~K}$ for the PUREX tunnel shielded option, and $\$ 3,250 \mathrm{~K}$ for the CWC option. The basis for these estimates are provided in Appendices B and C.

\subsubsection{High Level Vault Tank Residuals}

This section addresses the 20 metal filters containing mixed TRU waste, one TRU column, two filters containing strontium, and nine cesium-containing ion exchange columns. Details for each waste stream, including volume, activity levels, and waste classification are provided in Section 2.0 of this report. The following options are considered in this section: 1) placing the metal filters in lead-lined 55-gallon drums, 2) placing the filter canisters in SWDB, and 3) encapsulating the IX columns in grout containers and shipping them to the LLW burial ground (IX columns are verified LLW)

The interim storage location for each container that are considered in this section is as follows:

- The 55-gallon lead-lined drums will be stored at the CWC.

- $\quad$ The SWDB containing the waste and filters will be stored at CWC.

- The SWDB containing the waste will be stored in PUREX Tunnel 2.

- $\quad$ The engineered containers with the waste will be stored in PUREX Tunnel 2. 
HNF-2570, Rev. 0

Assuming that the majority of the curie content originates from Sr-90, the total DE-Ci of the filters and IX column are estimated to be as follows: metal filters $(646+2067+9 \mathrm{KCi}) \times 2 \times$ $3.02 \times 10^{-3}=74.5 \mathrm{DE}-\mathrm{Ci}$. Based on the waste classification and activity levels, the waste is well within the acceptance criteria for shipment to $\mathrm{CWC}$ for storage in the packaging options discussed in this section.

\subsubsection{Prepackaging Activities}

55-Gallon Drums. Ensure that filters do not contain liquids: otherwise no prepackaging activities are required.

Shielded Box. Ensure that filters do not contain liquids; place filters and columns into the SWDB liner and cask; no other prepackaging activities are required. A SWDB can hold eight engineered containers.

Grout Containers. This option only applies to the nine IX columns. The movement of grout containers out of the 324 Building will be accomplished in 382-B casks. No other prepackaging activities are required.

\subsubsection{Packaging Activities.}

Table 5-3 indicates the number of 55-gallon lead-lined drums that are required if all the filters and the TRU column are packaged in them.

Table 5-3. Packaging Approach for Storage of HLV Residuals at CWC.

\begin{tabular}{|l|l|c|}
\hline \multicolumn{1}{|c|}{ Waste Stream } & \multicolumn{1}{c|}{ Package } & $\begin{array}{c}\text { Packages } \\
\text { Required }\end{array}$ \\
\hline 20 metal filters & Lead-lined drum & 20 \\
\hline TRU column & Lead-lined drum & 1 \\
\hline Strontium filters & Lead-lined drum & 2 \\
\hline Cesium IX column & Grout container & 9 \\
\hline
\end{tabular}


Table 5-4 indicates the number of packages required if the waste is placed in engineered containers for storage. The engineered containers would be shipped and/or stored in a SWDB.

\begin{tabular}{|l|c|c|}
\hline \multicolumn{3}{|c|}{ Table 5-4. Packaging Approach for Storage of HLV Residuals } \\
in the PUREX Tunnels. \\
\hline Waste Stream & \multicolumn{1}{|c|}{ Package } & $\begin{array}{c}\text { Packages } \\
\text { Required }\end{array}$ \\
\hline 20 metal filters & engineered container & 7 \\
\hline $\begin{array}{l}\text { TRU column and } \\
\text { strontium filters }\end{array}$ & engineered container & 1 \\
\hline
\end{tabular}

\subsubsection{Transportation Activities.}

Transport to CWC and PUREX Tunnel 2 will be by truck. The 55-gallon lead-lined drums will be placed in an overpack for shipment. The SWDB will be transported in an impactlimiter assembly to prevent collision damage. Table 5-5 lists the number of shipments required for each storage option.

\begin{tabular}{|l|c|}
\hline \multicolumn{2}{|c|}{$\begin{array}{c}\text { Table 5-5. Shipping Approaches for Sending the } \\
\text { HLV Residuals to the CWC. }\end{array}$} \\
\hline \multicolumn{1}{|c|}{ Storage Option } & Shipments Required \\
\hline Lead-lined drum & 2 drums/shipment $=12$ \\
\hline SWDB & assume by truck $=1$ \\
\hline Grout containers & assume by truck $=9$ \\
\hline
\end{tabular}

\subsubsection{Placement Activities.}

Removing the cask liners from the SWDB at the PUREX tunnels is the only off-normal placement activity to be considered. This activity includes removing the impact limiter to allow access to the lid, the SWDB lid, then removing the liner from the SWDB. The engineered containers will be confined inside the SWDB liner. The operation would be performed remotely for the protection of the workers. Other placement activities are simple, routine operations of removing the containers from the transport vehicle.

\subsubsection{Post Placement Activities.}

Post-placement activities are those activities performed at the package's final destination. The activities start after the package has been removed from the transport vehicle and end when 
the waste package is at its interim storage location. For the PUREX tunnel option, postplacement cost for the SWDB includes labor for two health physics technicians, one equipment operator, one supervisor, and two nuclear operators for five hours.

\subsubsection{Cost Summary.}

Fixed costs to prepare the storage locations (PUREX Tunnels options and CWC) were provided in Section 4.5. The additional costs to prepare, package, transport, place and maintain the HLV residuals is estimated to be $\$ 142 \mathrm{~K}$ for the PUREX tunnel unshielded option, $\$ 225 \mathrm{~K}$ for the PUREX tunnel shielded option, and $\$ 685 \mathrm{~K}$ for the CWC option. The bases for these estimates are provided in Appendices B and C.

\subsection{Evaluation By Alternative}

This section will provide the evaluation of the alternatives. The costs within the variable cost tables include only those activities that would be performed differently between the alternatives. Similar activities (i.e., cell support, manipulator maintenance, project management) have not been included.

Table 5-6 summarizes the findings for each alternative.

\begin{tabular}{|l|r|r|r|}
\hline \multicolumn{5}{|c|}{ Table 5-6. Alternative Evaluation Summary. } \\
\hline & $\begin{array}{c}\text { PUREX Option \#1 } \\
\text { Unshielded - PUREX } \\
\text { Tunnel 2 }\end{array}$ & $\begin{array}{c}\text { PUREX Option \#2 } \\
\text { Shielded - } \\
\text { PUREX Tunnel 2 }\end{array}$ & CWC \\
\hline Fixed Costs & $\$ 1,632$ & $\$ 937$ & $\$ 950$ \\
\hline & \multicolumn{3}{|r|}{ Variable Costs } \\
\hline $\begin{array}{l}\text { B-Cell } \\
\text { Disperse }\end{array}$ & $\$ 857$ & $\$ 1,314$ & $\$ 3,250$ \\
\hline HLV residual & $\$ 142$ & $\$ 225$ & $\$ 685$ \\
\hline Total costs & $\$ 2,631$ & $\$ 2,476$ & $\$ 4,885$ \\
\hline
\end{tabular}


HNF-2570, Rev. 0

This page intentionally left blank. 
HNF-2570, Rev. 0

\subsection{RECOMMENDED STORAGE SOLUTION}

Table 6-1 provides the recommendations for the proposed storage for the 324 Building SCW based on the evaluation in the preceding sections.

Table 6-1. Recommendations

\begin{tabular}{|l|l|l|l|l|l|}
\hline \multicolumn{1}{|c|}{ Waste Stream } & Storage Option & Container & $\begin{array}{l}\text { Schedule } \\
\text { Available }\end{array}$ & \multicolumn{1}{|c|}{$\begin{array}{c}\text { Lowest Cost } \\
\text { Option }\end{array}$} & \multicolumn{1}{|c|}{ Justification } \\
\hline $\begin{array}{l}\text { 324 B-Cell dispersibles/tank } \\
\text { heels }\end{array}$ & PUREX Tunnel & SWDB & Jan 00 & PUREX Tunnel . & $\begin{array}{l}\text { Lowest cost. Consolidates } \\
\text { B-Cell dispersibles in one } \\
\text { location. Least handling. } \\
\text { Does not preclude future } \\
\text { retrieval/processing. }\end{array}$ \\
\hline 324 HLV filters/IX columns & PUREX Tunnel & SWDB & Jan 00 & PUREX Tunnel & $\begin{array}{l}\text { Lowest cost. Does not } \\
\text { preclude future } \\
\text { retrieval/processing. }\end{array}$ \\
\hline
\end{tabular}


HNF-2570, Rev. 0

This page intentionally left blank. 
HNF-2570, Rev. 0

\subsection{REFERENCES}

10 CFR 61, 1992, "Licensing Requirements for Land Disposal of Radioactive Waste," Code of Federal Regulations, as amended.

40 CFR 61.07, "Application for Approval of Construction/Modification to an Existing Radioactive Air Emissions Source," Code of Federal Regulations, as amended.

49 CFR 173, 1991, "Shippers-General Requirements for Shipments and Packaging," Code of Federal Regulations, as amended.

49 CFR 263, "Appendix B, Applicable Environmental Statutes, Regulations, and Orders," Code of Federal Regulations, as amended.

Bendixsen, 1997, CWC Interim Operational Safety Requirements, HNF-SD-WM-TSR-005, Fluor Daniel Northwest, Richland, Washington.

Bendixsen, R. B., 1997, Central Waste Complex Interim Safety Basis, HNF-SD-WM-ISB-007, Rev. 0, Fluor Daniel Northwest, Richland, Washington.

DOE, 1985, Final Environmental Impact Statement - Disposal of Hanford Defense High Level, Transuranic and Tank Wastes, DOE/EIS-0113, U.S. Department of Energy, Washington, D.C., Hanford Site, Richland, Washington

DOE, 1988, Radioactive Waste Management, DOE Order 5820.2A, U.S. Department of Energy, Washington, D.C.

DOE, 1992, Integrated Data Base for 1992: U.S. Spent Fuel and Radioactive Waste Inventories, Projections, and Characteristics, DOE/RW-0006, Rev. 8, U.S. Department of Energy, Washington, D.C.

DOE, 1995a, Environmental Assessment, Special-Case Waste Storage Facility, DOE/EA-0982, U.S. Department of Energy, Washington, D.C.

DOE, 1995b, Certificate of Compliance for Radioactive Materials Package, Beneficial Uses Shipping System, USA/9511/B( U), U.S. Department of Energy, Washington, D.C.

DOE-RL, 1988, Hanford Site Facility Dangerous Waste Part A Permit Application, DOE/RL-88-21, U.S. Department of Energy, Richland Operations Office, Richland, Washington.

DOE-RL, 1995, The Hanford Site Air Operating Permit Application, DOE/RL-95-07, U.S. Department of Energy, Richland Operations Office, Richland, Washington. 
DOE-RL, 1998, The 324 Building Radiochemical Engineering Cells, High-Level Vault, LowLevel Vault, and Associated Areas Closure Plan, Rev. 1, DOE/RL-96-73, U.S. Department of Energy, Richland Operations Office, Richland, Washington.

Ecology, EPA, and DOE, 1994, Hanford Federal Facility Agreement and Consent Order, Fourth and Fifth Amendment, 89-10.3, Washington State Department of Ecology, U.S. Environmental Protection Agency, U.S. Department of Energy, Olympia, Washington.

Ecology, 1996, Hanford Federal Facility Agreement and Consent Order, Change Number M-92-96-01 approved December 24, 1996, Washington State Department of Ecology, U.S. Environmental Protection Agency, and U.S. Department of Energy, Olympia, Washington.

GE, 1994, Model 2000 Radioactive Material Transport Package, 2000 Watts Decay Heat Upgrade Safety Analysis Report, NEDO-23218, GE Nuclear Energy, Pleasanton, California.

HNF-PRO-154, Rev. 0, Responsibilities and Procedures, for all Hazardous Material, dated October 1, 1997, PHMC, Richland, Washington.

HNF-1730, Rev. 1, 324/327 Facilities Special-Case Waste Assessment and Disposition Alternatives Analysis, dated March 1998, B\&W Hanford Company, Richland, Washington

HNF-IP-1289, Rev. 1, 324/327 Buildings Stabilization/Deactivation Project Management Plan, Dated March 1998, B\&W Hanford Company, Richland, Washington

Holton, L. K., 1991, Source Term Releases to B-Cell, memo to R. E. Heineman, Pacific Northwest Laboratory, dated April 25, 1991, Pacific Northwest Laboratory, Richland, Washington.

Holton, L. K., 1996, Dispersible Radiochemical Inventory in B-Cell 324 Building, letter to R. E. Heineman, Pacific Northwest Laboratory, dated June 19, 1991, Pacific Northwest Laboratory, Richland, Washington

Meyer, M. F., 1997, Interim Safety Basis for Solid Waste Facilities, T Plant, HNF-SDWM-ISB-006, Rev. 0, Rust Federal Services Hanford, Inc., Richland, Washington.

Meyer, 1997, Memorandum of Understanding: Radionuclide and Hazardous Material Source Term for the T Plant Safety Documents, (Appendix F to the Interim Safety Basis for Solid Waste Facilities, $T$ Plant, HNF-SD-WM-ISB-006, Rev. 0), Waste Management Hanford, Richland, Washington. 
O'Neill, 1997, Summary of Assumptions/Approximations for Calculating the Contents of Metals Filters, Strontium Filters, and Ion-Exchange Columns from the HLV Process, Letter to G. J. Sevigny, dated March 18, 1997, Pacific Northwest Laboratory, Richland, Washington..

NRC, 1992, Certificate of Compliance for Radioactive Materials Package the Model 1500, USA/5939/B( )F, U.S. Nuclear Regulatory Commission, Washington, D.C.

Owczarski, P. C., 1995, Hydrogen Concentration Profile Summary in PUREX Facility due to Interim Storage of 324 Building Wastes, letter report to J. H. Jarret of Pacific Northwest National Laboratory under Subcontract 263357-A-14 dated November 9, 1995, Science Applications International Corporation, Richland, Washington.

Parsons, 1997, 324/327 Facility Special-Case Waste Meeting Minutes, dated June 4, 1997, Parsons Infrastructure and Technology Group, Inc., Richland, Washington.

PNL, 1988, Safety Analysis Report (SAR) for the Steel Waste Package, PNL-MA-651, Rev. 1, Pacific Northwest National Laboratory, Richland, Washington.

PNNL, 1995, Selection and Evaluation of Alternatives for the Removal of Solid Remote-Handled Mixed Waste from the 324 Building, PNL-10623, Pacific Northwest National Laboratory, Richland, Washington

PNNL, 1996a, Manifest 96006, Dispersible EC-16, -18, -19, -21-25, 22.5 Box, shipped March 1, 1996, PNL-324-96-002, Pacific Northwest National Laboratory, Richland, Washington

PNNL, 1996b, Manifest 96004, Mixed Waste EC-14, -15, -17 Feed Cans, 1-13 and -15, shipped March 6, 1996, PNL-324-96-005, Pacific Northwest National Laboratory, Richland, Washington..

PNNL, 1996c, Determination of the Radioactive Material and Plutonium Holdup in Ducts and Piping in the 324 Building, PNNL-10935, January 1996.

PNNL, 1996d, Waste Analysis Plan for the 324 Building HLV Interim Removal Action Project, P. J. Weaver, June 1996.

RFS, 1997, Safety Analysis Report for Packaging (Onsite) for the GNS-12 Packaging, HNF-SD-TP-SARP-022, Rust Federal Services Inc., Northwest Operations for Fluor Daniel Hanford, Inc., Richland, Washington

RFS, 1997, Safety Analysis Report for Packaging (Onsite) CASTOR GSF Cask, HNF-SD-TPSARP-021, Rust Federal Services, Inc., Northwest Operations for Fluor Daniel Hanford, Inc., Richland, Washington. 
SAIC, 1995, Hydrogen Concentration Profile Summary in PUREX Facility due to Interim Storage of 324 Building Wastes, P. C. Owczarski, November 9, 1995, Science Applications International Corporation, Richland, Washington.

Sandia National Laboratory, Safety Analysis Report for Packaging, SAND83-0698, Revision 3, Sandia National Laboratory, Richland, Washington.

WAC 173-303, 1990, "Dangerous Waste Regulations," Washington Administrative Code, as amended.

WAC 246-247-060, "Approval to Construct/Modify an Air Emissions Unit," Washington Administrative Code, as amended.

Weaver, P. J., 1997, B-Cell Dispersible Debris, letter to R. M. Millikin, B \& W Hanford Company, dated October 9, 1997, Pacific Northwest National Laboratory, Richland, Washington.

WHC, 1996, Safety Analysis Report for Packaging (Onsite) Non-TRU, Non-Fissile Radioactive Material in the 55-Gallon Drum, SD-RE-SAP-024, Revision 1A, Westinghouse Hanford Company, Richland, Washington.

WHC, 1992, Transuranic Radioactive Material in the 55-Gallon Drum, Safety Analysis Report for Packaging (Onsite), WHC-SD-RE-SAP-033, Westinghouse Hanford Company, Richland, Washington.

WHC, 1996, Safety Analysis Report for Packaging (Onsite) Lead-Lined Drum/21-PF-1 Packaging System, WHC-SD-WM-SARP-001, Westinghouse Hanford Company, Richland, Washington.

WHC, 1996, Safety Evaluation for Packaging (Onsite) for the Concrete-Shielded RH TRU Drum for the 327 Postirradiation Testing Laboratory, WHC-SD-TP-SEP-051, Westinghouse Hanford Company, Richland, Washington.

WHC, 1997, Safety Analysis Report for Packaging (Onsite) for the Modified Fuel Spacer Burial Box, WHC-SD-TP-SARP-005, Westinghouse Hanford Company, Richland, Washington.

WHC, 1996, Safety Analysis Report for Packaging (Onsite) for Type B Quantities of Radioactive Material in Type A Boxes, WHC-SD-TP-SARP-018, Westinghouse Hanford Company, Richland, Washington.

Willis, N. P., 1993, Hanford Site Radioactive Solid Waste Acceptance Criteria, WHC-EP0063-4, Westinghouse Hanford Company, Richland, Washington. 
HNF-2570, Rev. 0

Wilkinson, R. E., 1997, B-Cell Dispersible Calculations, memo to R. M. Millikin, B\&W

Hanford Company, dated October 9, 1997, Parsons Infrastructure and Technology Group, Inc., Richland, Washington. 
HNF-2570, Rev. 0

Page left intentionally blank. 
HNF-2570, Rev. 0

\section{APPENDIX A \\ Dangerous Waste Concentrations in HLV Filters \\ and Ion Exchangers}

\section{Metal Filters}

\begin{tabular}{|l|c|c|c|}
\hline \multicolumn{4}{|c|}{ Table A-1. Metal Filters Dangerous Waste Concentration. } \\
\hline $\begin{array}{c}\text { Dangerous Waste } \\
\text { Containment }\end{array}$ & $\begin{array}{c}\text { Concentration* } \\
(\mathrm{mg} / \mathrm{L})\end{array}$ & $\begin{array}{c}\text { WAC 173-303-090 } \\
\text { Limit (mg/L) }\end{array}$ & $\begin{array}{c}\text { Dangerous Waste } \\
\text { Code }\end{array}$ \\
\hline Barium $(\mathrm{Ba})$ & 420 & 100 & D005 \\
\hline Cadmium $(\mathrm{Cd})$ & 71 & 1.0 & D006 \\
\hline Chromium $(\mathrm{Cr})$ & 247 & 5.0 & D007 \\
\hline Lead $(\mathrm{Pb})$ & 21 & 5.0 & D008 \\
\hline
\end{tabular}

${ }^{*}$ Calculated from HLV Data Sheet 3, Metal Filter Loading Log

\section{Strontium Filters and TRU Filters}

Summary of Assumptions/Approximations for Calculating the Contents of Metals Filters, Strontium Filters, and Ion-Exchange Columns from HLV Process, Sheet 2, prepared by G.

Sevigny, shows that there are no dangerous waste constituents or transuranics in $\mathrm{Sr}$ filters 1,2, and 3. Sr-4 and Sr-5 contain dangerous waste constituents above the WAC 173-303 limits as shown below in Tables A-2 and A-3. The TRU filter also contains dangerous waste as shown in Table A-4.

\begin{tabular}{|l|c|c|c|}
\hline \multicolumn{5}{|c|}{ Table A-2. Strontium Filter \#4. } \\
\hline $\begin{array}{c}\text { Dangerous Waste } \\
\text { Contaminant }\end{array}$ & $\begin{array}{c}\text { Concentration** } \\
(\mathrm{mg} / \mathrm{L})\end{array}$ & $\begin{array}{c}\text { WAC 173-303-090 } \\
\text { Limit }(\mathrm{mg} / \mathrm{L})\end{array}$ & $\begin{array}{c}\text { Dangerous Waste } \\
\text { Code }\end{array}$ \\
\hline Barium $(\mathrm{Ba})$ & 93.3 & 100 & N/A \\
\hline Cadmium $(\mathrm{Cd})$ & 6.7 & 1.0 & D006 \\
\hline Chromium $(\mathrm{Cr})$ & 53.33 & 5.0 & D007 \\
\hline Lead $(\mathrm{Pb})$ & None & 5.0 & N/A \\
\hline
\end{tabular}




\begin{tabular}{|l|c|c|c|}
\hline \multicolumn{5}{|c|}{ Table A-3. Strontium Filter \#5 } \\
\hline $\begin{array}{c}\text { Dangerous Waste } \\
\text { Contaminant }\end{array}$ & $\begin{array}{c}\text { Concentration** } \\
(\mathrm{mg} / \mathrm{L})\end{array}$ & $\begin{array}{c}\text { WAC 173-303-090 } \\
\text { Limits }(\mathrm{mg} / \mathrm{L})\end{array}$ & $\begin{array}{c}\text { Dangerous Waste } \\
\text { Code }\end{array}$ \\
\hline Cadmium (Cd) & None & 1.0 & N/A \\
\hline Chromium $(\mathrm{Cr})$ & 50 & 5.0 & D007 \\
\hline Lead $(\mathrm{Pb})$ & None & 5.0 & N/A \\
\hline
\end{tabular}

Tables A- 2 and A-3 show strontium Filter \#4 and 5 have dangerous waste contaminants. Sr-4 has D006 and D007 dangerous waste code categories and Sr-5 has D007 waste code category.

\begin{tabular}{|l|c|c|c|}
\hline \multicolumn{5}{|c|}{ Table A-4. TRU Filter. } \\
\hline $\begin{array}{c}\text { Dangerous Waste } \\
\text { Contaminant }\end{array}$ & $\begin{array}{c}\text { Concentration } * * \\
(\mathrm{mg} / \mathrm{L})\end{array}$ & $\begin{array}{c}\text { WAC 173-303-090 } \\
\text { Limits }(\mathrm{mg} / \mathrm{L})\end{array}$ & $\begin{array}{c}\text { Dangerous Waste } \\
\text { Code }\end{array}$ \\
\hline Barium $(\mathrm{Ba})$ & 11.7 & 100 & N/A \\
\hline Cadmium $(\mathrm{Cd})$ & 0.64 & 1.0 & N/A \\
\hline Chromium $(\mathrm{Cr})$ & 6.38 & 5.0 & D007 \\
\hline Lead $(\mathrm{Pb})$ & None & 5.0 & N/A \\
\hline
\end{tabular}

Table A-4 shows TRU filter also has D007 dangerous waste category.

**Calculated from Summary of Assumptions/Approximations for Calculating the Contents of Metal Filters, Strontium Filters, and Ion Exchange Columns from HLV Process, by G. Sevigny.

Cs IX Columns

Cesium Ion Exchange Column Loading Log documents the analysis results of the core samples. These results do not show any dangerous waste or transuranic constituents. 
HNF-2570, Rev. 0

\section{APPENDIX B}

Summary of Waste Disposal Options

\section{B.1 B-CELL DISPERSIBLE}

\section{B.1.1 Prepackaging}

\begin{tabular}{|l|c|c|c|}
\hline \multicolumn{4}{|c|}{ Table B-1. B-Cell Dispersible Prepackaging Costs. } \\
\hline & PUREX Unshielded & PUREX Shielded & CWC Shielded \\
\hline Labor & $852 \mathrm{Wh}$ & $.932 \mathrm{Wh}$ & $2,114 \mathrm{Wh}$ \\
\hline Non-labor & $\$ 530,453$ & $\$ 1,001,253$ & $\$ 2,417,130$ \\
\hline
\end{tabular}

The major cost difference in this section is the procurement of liners and casks, for the PUREX Unshielded option, the main procurement is for SWDB liners, the PUREX Shielded option requires the procurement of five shielded SWDB Casks (including liners) at $\$ 100 \mathrm{~K}$ each. The CWC option uses two GNS- 12 casks and associated liners, two JMTR casks and associated liners, and five Castor casks and associated liners. Of these items, only the JMTR casks have no costs. The increased amount in labor hours pertaining to the CWC Shielded Option is due to additional engineering time associated with a more complex technical work plan because this option must address loading of three types of casks. In addition, work hours are higher because a safety assessment must be performed for the three new types of liners (the safety assessment on SWDB liners already exists).

\section{B.1.2 Packaging}

Table B-2. B-Cell Dispersible Packaging Costs.

\begin{tabular}{|l|c|c|c|}
\hline & PUREX Unshielded & PUREX Shielded & CWC Shielded \\
\hline Labor & $2,116 \mathrm{Wh}$ & $2,116 \mathrm{Wh}$ & $9,400 \mathrm{Wh}$ \\
\hline Non-labor & $\$ 14,044$ & $\$ 14,044$ & $\$ 27,630$ \\
\hline
\end{tabular}

The CWC Option has significantly higher labor hours because three types of casks are used, requiring three dry runs before actual loadout of the waste. Additionally, the CWC option requires the inner liners to be transferred to the Shielded Materials Facility for seal/welding. Additional non-labor dollars in the CWC Option is largely because of the NDE costs associated with the seal weld of inner containers. Finally, the CWC option requires nine outer containers/casks to be packaged and loaded out, resulting in higher labor hours than the PUREX options which both only require five outer containers/casks to be packaged and loaded out. There are no differences in packaging between the PUREX Unshielded and Shielded Options 
because the same volume of dispersibles will be collected and placed into the same amount/type of liners.

Note: Rad waste disposal charges associated with airlock work have been removed from this estimate.

\section{B.1.3 Transportation}

\begin{tabular}{|l|c|c|c|}
\hline \multicolumn{5}{|c|}{ Table B-3. B-Cell Dispersible Transportation Costs. } \\
\hline & PUREX Unshielded & PUREX Shielded & CWC Shielded \\
\hline Labor & $400 \mathrm{Wh}$ & $400 \mathrm{Wh}$ & $720 \mathrm{Wh}$ \\
\hline Non-labor & $\$ 25,100$ & $\$ 25,100$ & $\$ 42,120$ \\
\hline
\end{tabular}

There are no differences in the costs between the two PUREX options since the same type and quantity of shipping containers are being placed onto the trailers for shipment. Additional labor hours in the CWC option are caused by increased shipping manifests and off-loading associated with nine shipments to CWC versus five shipments to PUREX in the other options.

\section{B.1.4 Placement}

Table B-4. B-Cell Dispersible Placement Costs.

\begin{tabular}{|l|c|c|c|}
\hline & PUREX Unshielded & PUREX Shielded & CWC Shielded \\
\hline Labor & $1320 \mathrm{Wh}$ & $960 \mathrm{Wh}$ & $1204 \mathrm{Wh}$ \\
\hline Non-Labor & $\$ 41,150$ & $\$ 41,150$ & $\$ 42,120$ \\
\hline
\end{tabular}

The PUREX Unshielded Option has greater work hours than the Shielded Option because of greater engineering hours on Job Safety Analysis, as well as an increased effort in operations to unload the inner liners from the SWDB casks in the tunnel. CWC labor hours are relatively close to the PUREX Shielded Option because both options require off loading a cask only, and not pulling liners from casks 
HNF-2570, Rev. 0

\section{B.2.0 324 HLV FILTERS AND ION EXCHANGE COLUMNS}

\section{B.2.1 Prepackaging}

Table B-5. 324 HLV Filter and Ion Exchange Column Prepackaging Costs.

\begin{tabular}{|l|l|l|l|}
\hline & PUREX Unshielded & \multicolumn{1}{|c|}{ PUREX Shielded } & \multicolumn{1}{c|}{ CWC Shielded } \\
\hline Labor & $552 \mathrm{Wh}$ & $592 \mathrm{Wh}$ & $492 \mathrm{Wh}$ \\
\hline Non-Labor & $\$ 12,840$ & $\$ 107,00$ & $\$ 399,913$ \\
\hline
\end{tabular}

The CWC Option has the highest non-labor dollars because of the cost of purchasing 23 leadlined drums. The PUREX Shielded Option has higher non-labor dollars than the PUREX Unshielded Option because one shielded SWDB Cask (including liners) must be purchased at $\$ 100 \mathrm{~K}$. Labor hours in the PUREX Shielded Option are slightly higher than the PUREX Unshielded Option because the technical work plan has more engineering hours (the Shielded Option has not been performed in the past).

\section{B.2.2 Packaging}

Table B-6. 324 HLV Filter and Ion Exchange Column Packaging Costs.

\begin{tabular}{|l|l|l|l|}
\hline & PUREX Unshielded & \multicolumn{1}{|c|}{ PUREX Shielded } & \multicolumn{1}{c|}{ CWC Shielded } \\
\hline Labor & $1,020 \mathrm{Wh}$ & $1,020 \mathrm{Wh}$ & $2,744 \mathrm{Wh}$ \\
\hline Non-Labor & $\$ 2,809$ & $\$ 2,809$ & $\$ 28,890$ \\
\hline
\end{tabular}

The CWC Option has significantly higher labor hours because of the completion of a SARP for the lead-lined drums (already completed for the SWDB). Additionally, the CWC Option required six manned airlock entries to loadout the filter cans into the lead-lined drums, whereas the PUREX options only require one airlock entry. The CWC Option has higher non-labor dollars because of increased miscellaneous equipment/tools and NDA costs associated with the increased number of waste packages and shipments required. There are no differences between PUREX Options because both options loadout the same number and type of waste packages. 
HNF-2570, Rev. 0

\section{B.2.3 Transportation}

Table B-7. 324 HLV Filter and Ion Exchange Column Transportation Costs.

\begin{tabular}{|l|l|l|l|}
\hline & PUREX Unshielded & \multicolumn{1}{|c|}{ PUREX Shielded } & \multicolumn{1}{c|}{ CWC Shielded } \\
\hline Labor & $80 \mathrm{Wh}$ & $80 \mathrm{Wh}$ & $384 \mathrm{Wh}$ \\
\hline Non-Labor & $\$ 5,020$ & $\$ 5,020$ & $\$ 8,160$ \\
\hline
\end{tabular}

There are no differences in the costs between the two PUREX options because the same type and quantity of shipping containers are being placed onto the railcar for shipment. However the CWC Option has slightly higher non-labor dollars as result of the shipments. CWC will require 12 shipments and the PUREX options only required one shipment. Additional labor hours in the CWC option are because of the increased number of shipments and associated work to place waste packages onto the truck and associated Rad Shipper time associated with releasing shipments.

\section{B.2.4 Placement}

Table B-8. 324 HLV Filter and Ion Exchange Column Placement Costs.

\begin{tabular}{|l|l|l|l|}
\hline & PUREX Unshielded & \multicolumn{1}{|c|}{ PUREX Shielded } & \multicolumn{1}{c|}{ CWC Shielded } \\
\hline Labor & $440 \mathrm{Wh}$ & $316 \mathrm{Wh}$ & $624 \mathrm{Wh}$ \\
\hline Non-Labor & $\$ 8,230$ & $\$ 1,020$ & $\$ 20,160$ \\
\hline
\end{tabular}

The PUREX Unshielded Option has greater work hours than the Shielded Option because more engineering hours are required on Job Safety Analysis, as well as an increased effort in operations to unload the inner liners from the SWDB casks in the tunnel. CWC labor hours are higher than both PUREX options because of off loading an increased number of waste shipments. Non-labor dollars are higher for the CWC Option as a result increased transportation and rigging costs because of increased number of waste shipments. 
HNF-2570, Rev. 0

APPENDIX C

C-1 


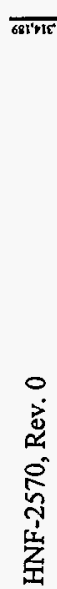

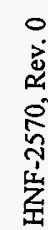

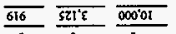

00001 ;

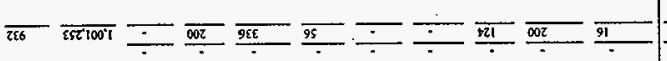
ooz oze of
91

stI 091

9I

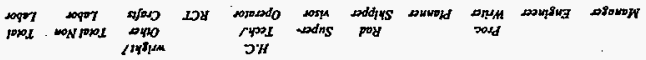

or

dogn 7

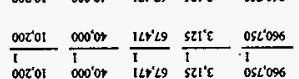

\section{1}

coosis $\frac{001 \mathrm{~s}}{001 \mathrm{t} s} \frac{00002}{-} \div \frac{050 \mathrm{~T}}{-} \div \frac{000 \mathrm{~s}}{-}$ $000^{\circ} 02 \quad 050^{\circ} 1$ $\cos s t \quad s$ 612 sz'ह

002

001

$\infty 1$

$\frac{.}{\cos 59} \div \frac{}{-} \frac{0 S L S E 6}{-}$

000 'sz

861

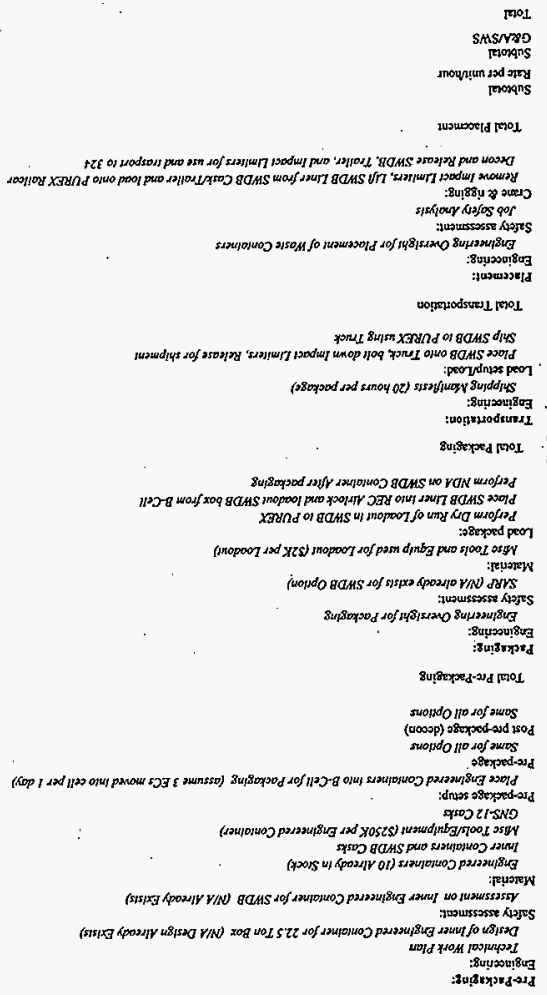

1usworotd triol

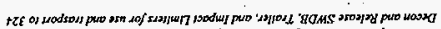

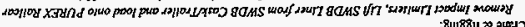

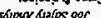
juxtussoss Apres

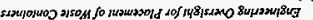

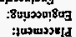

uoprodsural mol

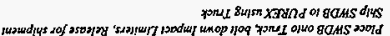

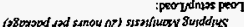

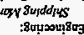
:aonviodecioxi

Euperped nol

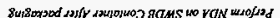

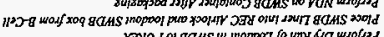

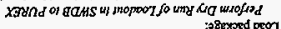

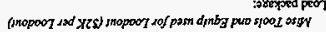
(WOF⿻ 8uponso :8uyesugoug 8u!gexped-20d [moL suondo Hio sof owits

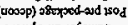

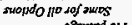

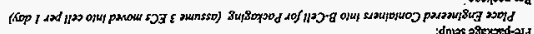

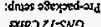

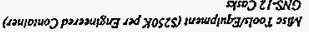

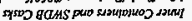

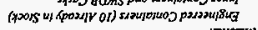

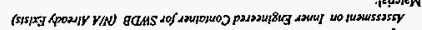

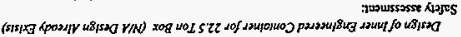
Wild XTo

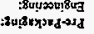




\section{PRE.PACKAGING}

Engincering:

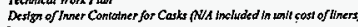

Pecform dsessment on Safely o/ 3 Type of Liners

GNS 12 Cast

GNSI2 Luers

MTR Casks

MimR Linens

Castor Casks

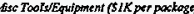

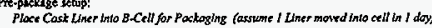

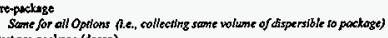

Post pre-packse (docon)

Toul Pre-Peckuging

PACKAGING:

Enginorisg:

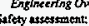

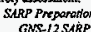

GNS-12SAPP

MMR SSRP

Cotris:

Afiso Tools and Equip wed for Loadout (S2K per loadowit)

Losd packascer

Thousfer Inner Liner fo SAF to Heldsed

Weld Seal Inner Inserr and Pasform NDE in S.SOFF

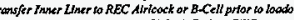

Pafom Dop Rim of booder

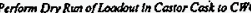

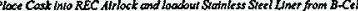

Toul Packaging

TRANSPORTATTON:

Engiscering:

Losd ceupl Lasd:

Plase Cosk onio Trusk bolt down impoct Limtiers, Relecse for shipment

Strp Cast to CHC when Truck

Totul Transportution

\section{PLACEMENT:}

Engincering:

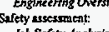

Jab Sagely dmatyr

Crane \& rigsing

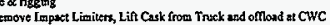

Decon und Relcose Trekk for use, Trassport beck to 324 with Impact Limiters

Total Ptacement

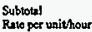

Gublowal

Toul

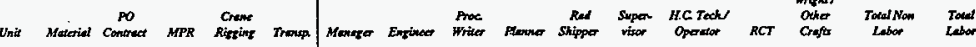

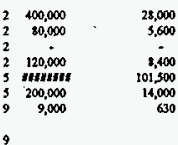

$72 \quad 576 \quad 360$

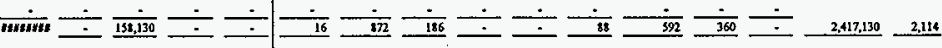

240

18,000

$9.000 \quad 60$

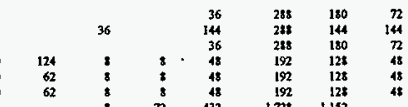

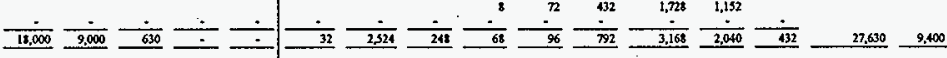

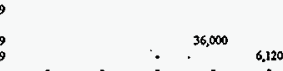

$14 \quad 36$ i44 i44 in

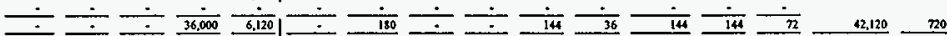

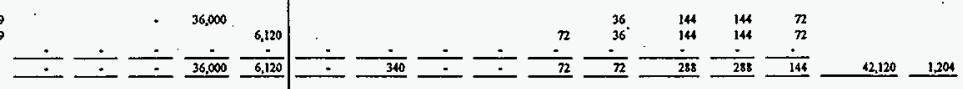

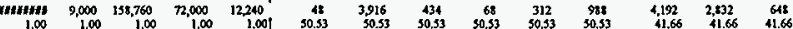

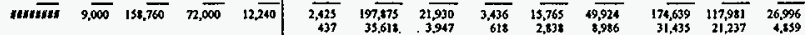

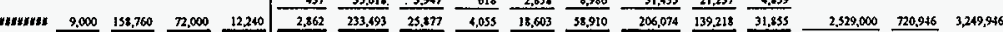




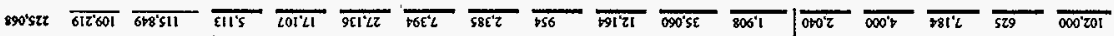

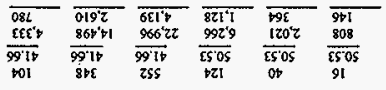

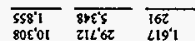

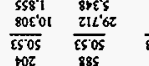

$\frac{219^{\prime 1}}{2 s^{\prime} 05}$

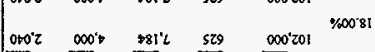

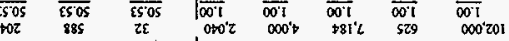

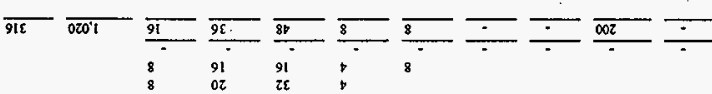
$\frac{1}{\text { ozo'1 }} \div \div \frac{-}{-} \div$ 081 or

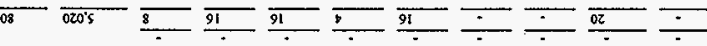
8 91 91 91

$\overline{0701 \mathrm{i}} \overline{608 \mathrm{z}}$ $\begin{array}{lll}2 \varepsilon & 8 & 8 \\ 81 & 08 & 821 \\ 821 & 26 \mathrm{I}\end{array}$

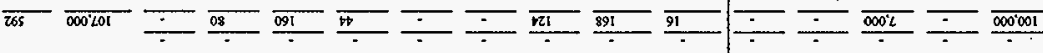
at $08 \quad 08$

or $\quad 8$
$\$ 21$ $91 \quad 91$

$\infty$

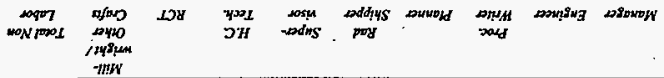
yogry

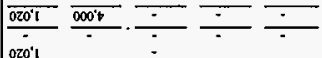

000

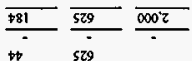

$000^{\circ} \mathrm{r}$

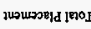

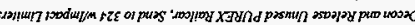

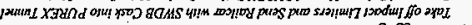

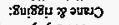
siscipoxy dififos qor

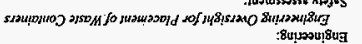
:INGW3ว

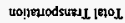

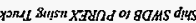

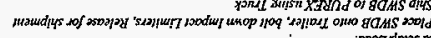

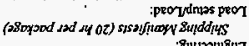
8utipouigua :NOLYLYOASNYY

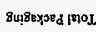

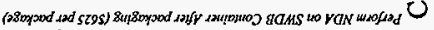

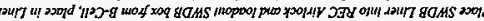

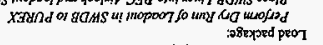

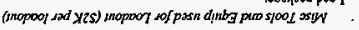

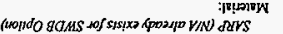

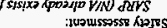

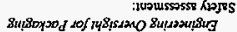
Su!cosulgug :ONIDY\%OV

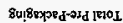

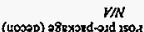

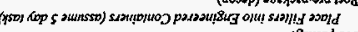

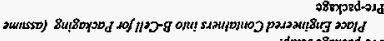

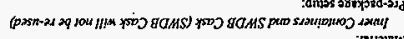

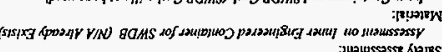

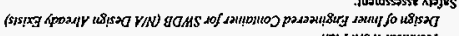

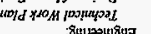
:DNIDYTJYA-Td 
HNF-2570, Rev. 0
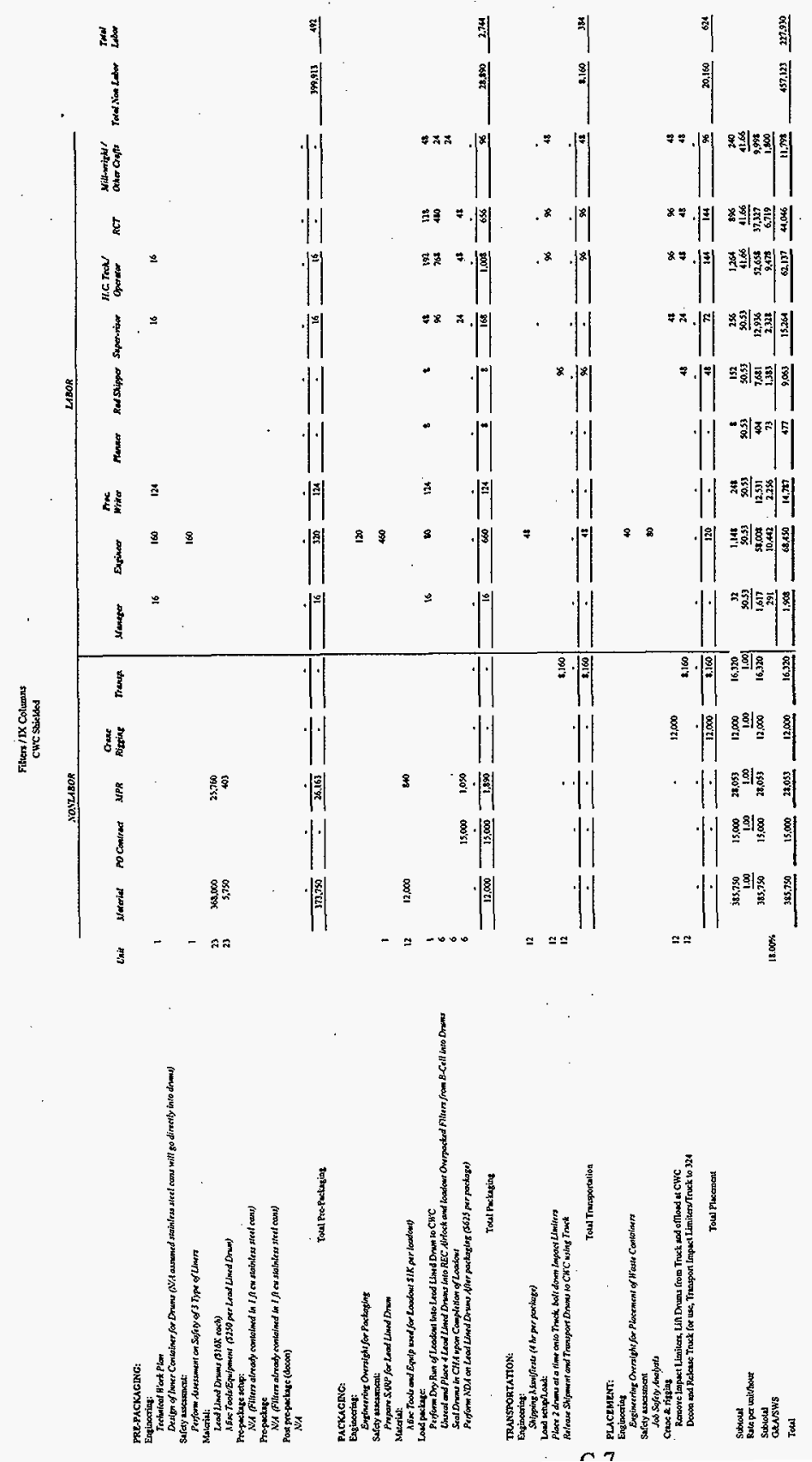